\title{
Influence of aerosol acidity on the chemical composition of secondary organic aerosol from $\boldsymbol{\beta}$-caryophyllene
}

\author{
M. N. Chan ${ }^{1}$, J. D. Surratt ${ }^{2, *}$, A. W. H. Chan ${ }^{2, * *}$, K. Schilling ${ }^{2}$, J. H. Offenberg ${ }^{3}$, M. Lewandowski ${ }^{3}$, E. O. Edney ${ }^{3}$, \\ T. E. Kleindienst ${ }^{3}$, M. Jaoui ${ }^{4}$, E. S. Edgerton ${ }^{5}$, R. L. Tanner ${ }^{6}$, S. L. Shaw ${ }^{7}$, M. Zheng ${ }^{8}$, E. M. Knipping ${ }^{9}$, and \\ J. H. Seinfeld ${ }^{1,2}$ \\ ${ }^{1}$ Division of Engineering and Applied Science, California Institute of Technology, Pasadena, California, USA \\ ${ }^{2}$ Division of Chemistry and Chemical Engineering, California Institute of Technology, Pasadena, California, USA \\ ${ }^{3}$ National Exposure Research Laboratory, Human Exposure Atmospheric Sciences Division, United States Environmental \\ Protection Agency, Research Triangle Park, North Carolina, USA \\ ${ }^{4}$ Alion Science and Technology, P.O. Box 12313, Research Triangle Park, North Carolina, USA \\ ${ }^{5}$ Atmospheric Research and Analysis, Inc., Cary, North Carolina, USA \\ ${ }^{6}$ Environmental Technologies, Tennessee Valley Authority, Muscle Shoals, Alabama, USA \\ ${ }^{7}$ Electric Power Research Institute, Palo Alto, California, USA \\ ${ }^{8}$ School of Earth and Atmospheric Sciences, Georgia Institute of Technology, Atlanta, Georgia, USA \\ ${ }^{9}$ Electric Power Research Institute, Washington, DC, USA \\ * present address: Department of Environmental Sciences and Engineering, University of North Carolina at Chapel Hill, \\ Chapel Hill, North Carolina, USA \\ ** present address: Department of Environmental Science, Policy and Management, University of California, Berkeley, \\ California, USA
}

Received: 18 November 2010 - Published in Atmos. Chem. Phys. Discuss.: 30 November 2010

Revised: 10 February 2011 - Accepted: 15 February 2011 - Published: 25 February 2011

\begin{abstract}
The secondary organic aerosol (SOA) yield of $\beta$ caryophyllene photooxidation is enhanced by aerosol acidity. In the present study, the influence of aerosol acidity on the chemical composition of $\beta$-caryophyllene SOA is investigated using ultra performance liquid chromatography/electrospray ionization-time-of-flight mass spectrometry (UPLC/ESI-TOFMS). A number of first-, second- and higher-generation gas-phase products having carbonyl and carboxylic acid functional groups are detected in the particle phase. Particle-phase reaction products formed via hydration and organosulfate formation processes are also detected. Increased acidity leads to different effects on the abundance of individual products; significantly, abundances of organosulfates are correlated with aerosol acidity. To our knowledge, this is the first detection of organosulfates and nitrated organosulfates derived from a sesquiterpene. The increase of certain particle-phase reaction products with increased acidity provides chemical evidence to support the acid-enhanced
\end{abstract}

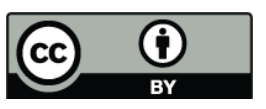

Correspondence to: J. H. Seinfeld (seinfeld@caltech.edu)
SOA yields. Based on the agreement between the chromatographic retention times and accurate mass measurements of chamber and field samples, three $\beta$-caryophyllene products (i.e., $\beta$-nocaryophyllon aldehyde, $\beta$-hydroxynocaryophyllon aldehyde, and $\beta$-dihydroxynocaryophyllon aldehyde) are suggested as chemical tracers for $\beta$-caryophyllene SOA. These compounds are detected in both day and night ambient samples collected in downtown Atlanta, GA and rural Yorkville, GA during the 2008 August Mini-Intensive Gas and Aerosol Study (AMIGAS).

\section{Introduction}

Secondary organic aerosol (SOA) formation from the oxidation of biogenic precursors, such as isoprene $\left(\mathrm{C}_{5} \mathrm{H}_{8}\right)$, monoterpenes $\left(\mathrm{C}_{10} \mathrm{H}_{16}\right)$, sesquiterpenes $\left(\mathrm{C}_{15} \mathrm{H}_{24}\right)$, and oxygenated terpenes, contributes significantly to atmospheric aerosol mass (Hallquist et al., 2009 and references therein). $\beta$-caryophyllene $\left(\mathrm{C}_{15} \mathrm{H}_{24}\right)$ is one of the most reactive sesquiterpenes, with two double bonds (one endocyclic and one exocyclic), and has high reactivity towards ozone $\left(\mathrm{O}_{3}\right)$,

Published by Copernicus Publications on behalf of the European Geosciences Union. 
hydroxyl radicals $(\mathrm{OH})$, and nitrate radicals $\left(\mathrm{NO}_{3}\right)$. Shu and Atkinson $(1994,1995)$ estimated that under typical tropospheric conditions the lifetime of $\beta$-caryophyllene with respect to $\mathrm{O}_{3}$ and $\mathrm{OH}$ reaction is $2 \mathrm{~min}$ and $53 \mathrm{~min}$, respectively. $\beta$-caryophyllene also has a high aerosol formation potential (Griffin et al., 1999; Jaoui et al., 2003; Lee et al., 2006a, b; Ng et al., 2006; Winterhalter et al., 2009; Li et al., 2011). A range of aerosol yields (mass of SOA formed per mass of hydrocarbon reacted) has been reported $\left(\mathrm{O}_{3}: 5-\right.$ 46\%; OH: 17-68\%), depending on aerosol organic mass and experimental conditions.

Particle-phase products of $\beta$-caryophyllene ozonolysis have been extensively studied in the presence or absence of ammonium sulfate $\left(\left(\mathrm{NH}_{4}\right)_{2} \mathrm{SO}_{4}\right)$ seed particles. A number of first-generation ozonolysis products, such as aldehydes (e.g., $\beta$-caryophyllon aldehyde and $\beta$-hydroxycaryophyllon aldehyde) and acids (e.g., $\beta$-caryophyllonic acid and $\beta$ caryophyllinic acid), have been identified (Calogirou et al., 1997; Jaoui et al., 2003; Kanawati et al., 2008; Winterhalter et al., 2009; Li et al., 2011). Ng et al. (2006) observed continued aerosol growth after all $\beta$-caryophyllene was consumed in ozonolysis and photooxidation experiments, demonstrating the importance of second- or highergeneration reactions. More recently, Li et al. (2011) showed that first-generation ozonolysis products, which still contain a double bond, can be oxidized to second-generation ozonolysis products (e.g., $\beta$-nocaryophyllon aldehyde and $\beta$ hydroxynocaryophyllon aldehyde), which represent a larger contribution to the SOA mass than first-generation ozonolysis products. $\beta$-caryophyllinic acid has been detected in both chamber and ambient aerosol samples and has been suggested as a tracer for $\beta$-caryophyllene SOA (Jaoui et al., 2007). Using the tracer-to-SOA mass fractions obtained in laboratory chamber experiments, $\beta$-caryophyllene SOA is estimated to contribute about $1-10 \%$ of the atmospheric aerosol organic mass in the southeastern and midwestern United States (Kleindienst et al., 2007; Lewandowski et al., 2008).

Chamber studies have shown that increasing aerosol acidity enhances SOA formation from the oxidation of certain biogenic hydrocarbons such as isoprene, $\alpha$-pinene, and $\beta$-pinene (Kroll and Seinfeld, 2008, and references therein). Acid-catalyzed reactions (e.g., hydration, esterification, hemiacetal/acetal formation, aldol condensation) leading to the formation of higher molecular-weight compounds have been proposed to explain the enhanced SOA yields (Jang et al., 2002). When the acidity is provided by sulfuric acid $\left(\mathrm{H}_{2} \mathrm{SO}_{4}\right)$, sulfate esters (or organosulfates) can form (Liggio and Li, 2006; Surratt et al., 2007a, b, 2008; Iinuma et al., 2009). By comparing mass spectrometric measurements for both laboratory-generated and ambient aerosol, Iinuma et al. (2007) and Surratt et al. (2007a, b, 2008) have reported the presence of organosulfates derived from isoprene, $\alpha$-pinene, $\beta$-pinene, and limonene-like monoterpenes (e.g., myrcene) in ambient aerosol.
SOA yields are enhanced by aerosol acidity in the photooxidation of mixtures of $\beta$-caryophyllene/ $\mathrm{NO}_{\mathrm{x}}$ (Offenberg et al., 2009). In the present study, the influence of aerosol acidity on the chemical composition of $\beta$ caryophyllene SOA from $\beta$-caryophyllene photooxidation is investigated using ultra performance liquid chromatography/electrospray ionization-time-of-flight mass spectrometry (UPLC/ESI-TOFMS). Certain $\beta$-caryophyllene reaction products are shown to serve as tracers for the identification of $\beta$-caryophyllene SOA in ambient aerosol collected in downtown Atlanta (at Jefferson Street (JST)), GA and rural Yorkville (YRK), GA during the 2008 August Mini-Intensive Gas and Aerosol Study (AMIGAS).

\section{Experimental section}

$\beta$-caryophyllene $/ \mathrm{NO}_{\mathrm{x}}$ irradiation experiments in the presence of seed aerosol of varying acidity were carried out in a $14.5 \mathrm{~m}^{3}$ fixed volume Teflon-coated reaction chamber at $297 \mathrm{~K}$ and $30 \% \mathrm{RH}$. Details of the experiments have been given in Offenberg et al. (2009). Initial aerosol acidity was controlled by nebulizing dilute aqueous $\left(\mathrm{NH}_{4}\right)_{2} \mathrm{SO}_{4} / \mathrm{H}_{2} \mathrm{SO}_{4}$ solutions. To change the acidity of the seed aerosol, the ratio of the two liquids was changed to produce a constant aerosol sulfate concentration of $30 \mu \mathrm{g} \mathrm{m}^{-3}$ across the range of resulting acidities. The reaction chamber was operated as a continuous stirred tank reactor, having a residence time of $6 \mathrm{~h}$, to produce a constant, steady-state aerosol distribution. For the aerosol acidity measurement, filters were extracted by sonication for $30 \mathrm{~min}$ using $10 \mathrm{~mL}$ of distilled, deionized water in a $50 \mathrm{~mL}$ polypropylene vial. Once the extract cooled to room temperature, the $\mathrm{pH}$ of each extract was measured with a Mettler-Toledo MP220 pH meter using an InLab 413 $\mathrm{pH}$ electrode. Aerosol acidity is expressed as the hydrogen ion air concentrations $\left(\left[\mathrm{H}^{+}\right]_{\text {air }}\right)$, which was calculated by dividing the measured aqueous concentration of the hydrogen ion by the volume of air collected. Table 1 summarizes the steady state concentrations of gas-phase species, aerosol acidity, and secondary organic carbon (SOC) for the experiments.

For the chemical analysis, aerosol was collected on Teflon impregnated glass fiber filters (Pall Gelman Laboratory, $47 \mathrm{~mm}$ diameter, Teflon impregnated). To collect sufficient aerosol mass for the analysis, about $0.7-1.0 \mathrm{mg}$ was collected on each filter and the sampling air volume was about $15.4-16.3 \mathrm{~m}^{3}$. One-half of each filter was extracted with methanol (LC-MS CHROMASOLV-grade, Sigma-Aldrich) under ultrasonication for $45 \mathrm{~min}$. The extract was dried under ultra-pure nitrogen gas and the residue was reconstituted with a 50:50 (v/v) solvent mixture of methanol with $0.1 \%$ acetic acid (LC-MS CHROMASOLV-grade, Sigma-Aldrich) and water with $0.1 \%$ acetic acid (LC-MS CHROMASOLVgrade, Sigma-Aldrich). Day (10:00 a.m.-06:00 p.m., local time)- and night (10:00 p.m.-06:00 a.m., local time) - 
Table 1. Steady state concentrations of gas-phase species, aerosol acidity, and secondary organic carbon (SOC) for $\beta$-caryophyllene/NO irradiation experiments, reproduced from Offenberg et al. (2009).

\begin{tabular}{lcccccc}
\hline Experiment & $\Delta[\mathrm{HC}](\mathrm{ppmC})$ & {$[\mathrm{NO}](\mathrm{ppbV})$} & {$\left[\mathrm{NO}_{\mathrm{x}}-\mathrm{NO}\right](\mathrm{ppbV})$} & $\mathrm{O}_{3}(\mathrm{ppbV})$ & {$\left[\mathrm{H}^{+}\right]_{\text {air }}\left(\mathrm{nmol} \mathrm{m}^{-3}\right)$} & $\left.\mathrm{SOC}(\mu \mathrm{gC} \mathrm{m})^{-3}\right)$ \\
\hline 1 & 0.58 & 60 & 51 & 25 & 112 & 9.97 \\
2 & 0.58 & 61 & 51 & 24 & 204 & 14.7 \\
3 & 0.58 & 63 & 54 & 29 & 467 & 21.3 \\
4 & 0.58 & 65 & 53 & 24 & 1150 & 34.0 \\
\hline
\end{tabular}

segregated $\mathrm{PM}_{2.5}$ (particulate matter with an aerodynamic diameter $<2.5 \mu \mathrm{m}$ ) high-volume quartz filter samples (i.e., quartz microfibre, $20.3 \times 25.4 \mathrm{~cm}$, Whatman) were collected from JST and YRK sites during the 2008 AMIGAS campaign was analyzed for the presence of $\beta$-caryophyllene SOA constituents. Details of the 2008 AMIGAS campaign, filter collection, and sample preparation procedures are given by Chan et al. (2010). Both chamber and field sample extracts were analyzed by UPLC/ESI-TOFMS operated in both positive and negative ion modes. Details of the UPLC/ESITOFMS analysis have been given in Surratt et al. (2008). All accurate mass measurements were within $\pm 5 \mathrm{mDa}$ of the theoretical mass associated with the proposed chemical formula for each observed ion. Owing to the lack of authentic standards or suitable surrogates, concentrations are reported as the sum of the UPLC chromatographic peak area of the ions normalized by the volume of air collected. From repeated UPLC/ESI-TOFMS measurements, the variations in the chromatographic peak areas are about 5\%. The concentrations are not corrected for extraction efficiencies.

\section{Results and discussion}

\subsection{Gas- and particle-phase reactions}

In the series of $\beta$-caryophyllene photooxidation experiments, $\beta$-caryophyllene and its gas-phase products react with $\mathrm{O}_{3}$ and $\mathrm{OH}$ in the presence of $\mathrm{NO}_{\mathrm{x}}$. Rate constants $(296 \mathrm{~K})$ for the reaction of $\beta$-caryophyllene with $\mathrm{O}_{3}$ $\left(k_{\mathrm{O}_{3}}=1.16 \times 10^{-14} \mathrm{~cm}^{3}\right.$ molecule $\left.{ }^{-1} \mathrm{~s}^{-1}\right)$ and $\mathrm{OH}\left(k_{\mathrm{OH}}=\right.$ $1.97 \times 10^{-10} \mathrm{~cm}^{3}$ molecule $\left.\mathrm{e}^{-1} \mathrm{~s}^{-1}\right)$ have been reported by Shu and Atkinson $(1994,1995)$. At steady state in the reaction chamber, the $\mathrm{O}_{3}$ level was $24-29 \mathrm{ppb}\left(5.93 \times 10^{11}\right.$ $7.16 \times 10^{11}$ molecules $\mathrm{cm}^{-3}$ ) (Table 1 ). The $\mathrm{OH}$ concentration in the chamber was not directly measured. At an assumed $\mathrm{OH}$ level of $10^{6}$ molecules $\mathrm{cm}^{-3}$, the ratio of the rates of $\beta$-caryophyllene reaction with $\mathrm{O}_{3}$ to $\mathrm{OH}$ at the $\mathrm{O}_{3}$ levels in the reaction chamber is about 36. $\beta$-caryophyllene ozonolysis is therefore likely the dominant reaction pathway in the first oxidization step. The two double bonds of $\beta$ caryophyllene have different reactivity with respect to $\mathrm{O}_{3}$. Nguyen et al. (2009) predicted that the rate coefficient for $\mathrm{O}_{3}$ attack on the exocyclic double bond is less than $5 \%$ of that for $\mathrm{O}_{3}$ attack on the endocyclic double bond. Thus, addition of $\mathrm{O}_{3}$ to the endocyclic double bond is likely the dominant reaction of $\beta$-caryophyllene with $\mathrm{O}_{3}$. Since $\mathrm{O}_{3}$ and $\mathrm{OH}$ are in excess relative to $\beta$-caryophyllene in the reaction chamber, the remaining double bond (either exocyclic or endocyclic) of the first-generation products undergoes a second ozonolysis or reacts with $\mathrm{OH}$, leading to second- or higher-generation products. Based on an average rate coefficient for the ozonolysis of the first-generation products $\left(k_{\mathrm{O}_{3}}=1.1 \times 10^{-16} \mathrm{~cm}^{3}\right.$ molecule $\left.{ }^{-1} \mathrm{~s}^{-1}\right)$ reported by Winterhalter et al. (2009) at $295 \mathrm{~K}$, the average lifetime of the firstgeneration products with respect to ozonolysis is about 3.5 to $4.2 \mathrm{~h}$. Rate coefficients for the photooxidation of the firstgeneration products have not been reported. If the rate coefficient for the photooxidation of $\beta$-caryophyllene is used $\left(k_{\mathrm{OH}}=1.97 \times 10^{-10} \mathrm{~cm}^{3}\right.$ molecule $\left.{ }^{-1} \mathrm{~s}^{-1}\right)$, as an approximation, the average lifetime of the first-generation products with respect to photooxidation is about $1.4 \mathrm{~h}$ at an $\mathrm{OH}$ level of $10^{6}$ molecules $\mathrm{cm}^{-3}$. Thus, the first generation products can be further oxidized in the gas phase at the residence time in the reaction chamber.

The gas-phase chemistry of $\beta$-caryophyllene in our system involves $\mathrm{OH}, \mathrm{O}_{3}$, and $\mathrm{NO}_{\mathrm{x}}$. For clarity and simplicity, we focus on the reactions of the first-generation products of $\beta$-caryophyllene in the gas and particle phases, leading to particle-phase products detected by UPLC/ESI-TOFMS (Scheme 1). Formation mechanisms of $\beta$-caryophyllon aldehyde, $\beta$-hydroxycaryophyllon aldehyde, $\beta$-oxocaryophyllon aldehyde, and $\beta$-norcaryophyllon aldehyde from the photooxidation and ozonolysis of $\beta$-caryophyllene have been proposed (Jaoui et al., 2003; Lee et al., 2006a, b; Winterhalter et al., 2009; Li et al., 2011). Additionally, ring-retaining compounds can form (Jaoui et al., 2003; Lee et al., 2006b). For example, $\beta$-caryophyllene oxide can form from the reaction of $\beta$-caryophyllene with $\mathrm{O}_{3}$ similar to $\alpha$-pinene oxide formation (Iinuma et al., 2009) and has been detected in both gas- and particle phases in the ozonolysis of $\beta$-caryophyllene (Jaoui et al., 2003). $\beta$-caryophylla ketone can form from $\beta$ caryophyllene reaction with $\mathrm{O}_{3}$ or $\mathrm{OH}$ at its exocyclic double bond (Jaoui et al., 2003; Lee et al., 2006b). The firstgeneration ring-retaining compounds, which contain an unreacted double bond, can be further oxidized before partitioning to the particle phase. 


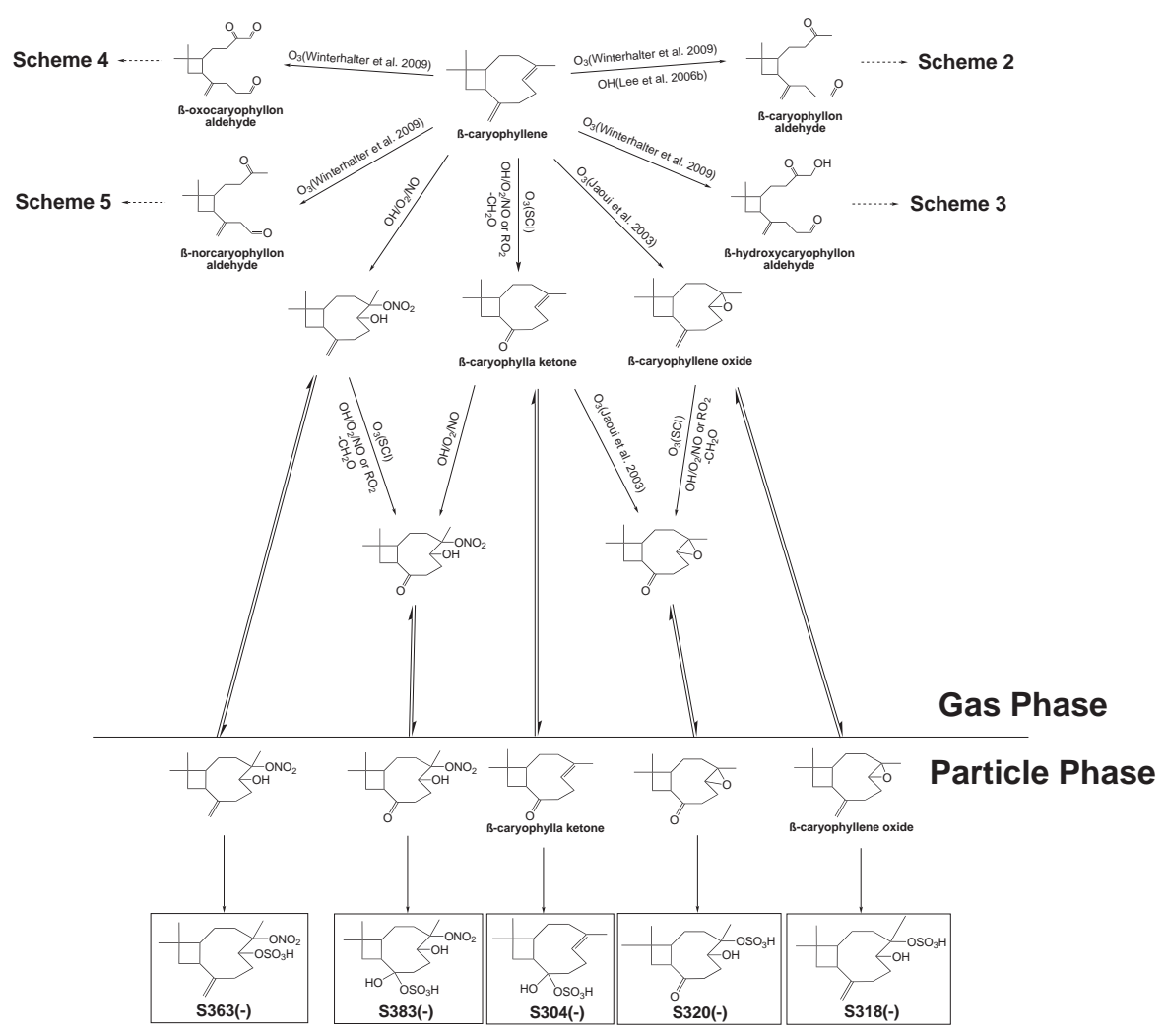

Scheme 1. Proposed reaction pathways of $\beta$-caryophyllene, leading to compounds detected by ESI in the particle phase. Boxes indicate compounds detected by ESI in the particle phase. One possible structural isomer is shown. SCI is the stabilized Criegee intermediates channel.

Schemes 2-5 show the further oxidation of the firstgeneration products, leading to compounds detected by ESI in the particle phase. In the presence of excess $\mathrm{O}_{3}$ and $\mathrm{OH}$, it can be assumed that the remaining double bond (exocyclic double bond) of the gas-phase products will be rapidly oxidized. Reaction of gas-phase products with $\mathrm{O}_{3}$ generally proceeds via four channels: stabilized Criegee intermediates (CIs), isomerization, hydroperoxide, and ester channels. Detailed reaction mechanisms for these channels have been given by Jaoui et al. (2003), Winterhalter et al. (2009), and Li et al. (2011). Stabilized CIs and hydroperoxide channels are considered to explain the formation of detected compounds. The stabilized CIs can react with $\mathrm{H}_{2} \mathrm{O}, \mathrm{NO}_{2}$, and carbonyls. The stabilized CIs channel (SCI) here refers to the reaction between the stabilized CIs and $\mathrm{H}_{2} \mathrm{O}$ or $\mathrm{NO}_{2}$ to form carbonyls. For example, $\beta$-caryophyllon aldehyde and $\beta$-caryophyllonic acid undergo oxidation by $\mathrm{O}_{3}$ on their exocyclic double bond forming $\beta$-nocaryophyllon aldehyde and $\beta$-nocaryophyllonic acid (Scheme 2). The stabilized CIs can react with carbonyls to form secondary ozonides (SOZ). Winterhalter et al. (2009) have detected the presence of SOZ in the particle phase using Fourier transform infrared spectroscopy in their $\beta$-caryophyllene ozonolysis experiments. SOZ were not detected in the particle phase in the present study. It is possible that SOZ may decompose to form organic acids in the particle phase under acidic conditions (or during the analytical procedure) (Winterhalter et al., 2009). For the hydroperoxide channel, the CIs can rearrange via a 1,4-hydrogen shift to a vinyl hydroperoxide, which can subsequently form hydroxyl carbonyls and dicarbonyls (Winterhalter et al., 2009). The hydroperoxide channel refers to the formation of hydroxyl carbonyls. For example, $\beta$ caryophyllon aldehyde undergoes oxidation by $\mathrm{O}_{3}$ on the exocyclic double bond forming $\beta$-hydroxynocaryophyllon aldehyde (Scheme 2).

The $\mathrm{OH}$ reaction with the exocyclic double bond of the gas-phase products forms alkyl radicals, followed by rapid addition of $\mathrm{O}_{2}$ to yield peroxy radicals. In the presence of $\mathrm{NO}_{\mathrm{x}}$, peroxy radicals react with $\mathrm{NO}$ to form either alkoxy radicals plus $\mathrm{NO}_{2}$ or organic nitrates. Alkoxy radicals can also form from the reactions between peroxy radicals. Alkoxy radicals can decompose, isomerize or react with $\mathrm{O}_{2}$. Here, alkoxy radicals are considered to undergo decomposition to produce a carbonyl and an alkyl radical $\left(\mathrm{CH}_{2} \mathrm{OH} \cdot\right)$. For example, $\beta$-nocaryophyllon aldehyde can form from the reaction of $\beta$-caryophyllon aldehyde with $\mathrm{OH}$ at its exocyclic double bond (Scheme 2). Many gas-phase products have an aldehyde group. An aldehydic hydrogen atom can be 


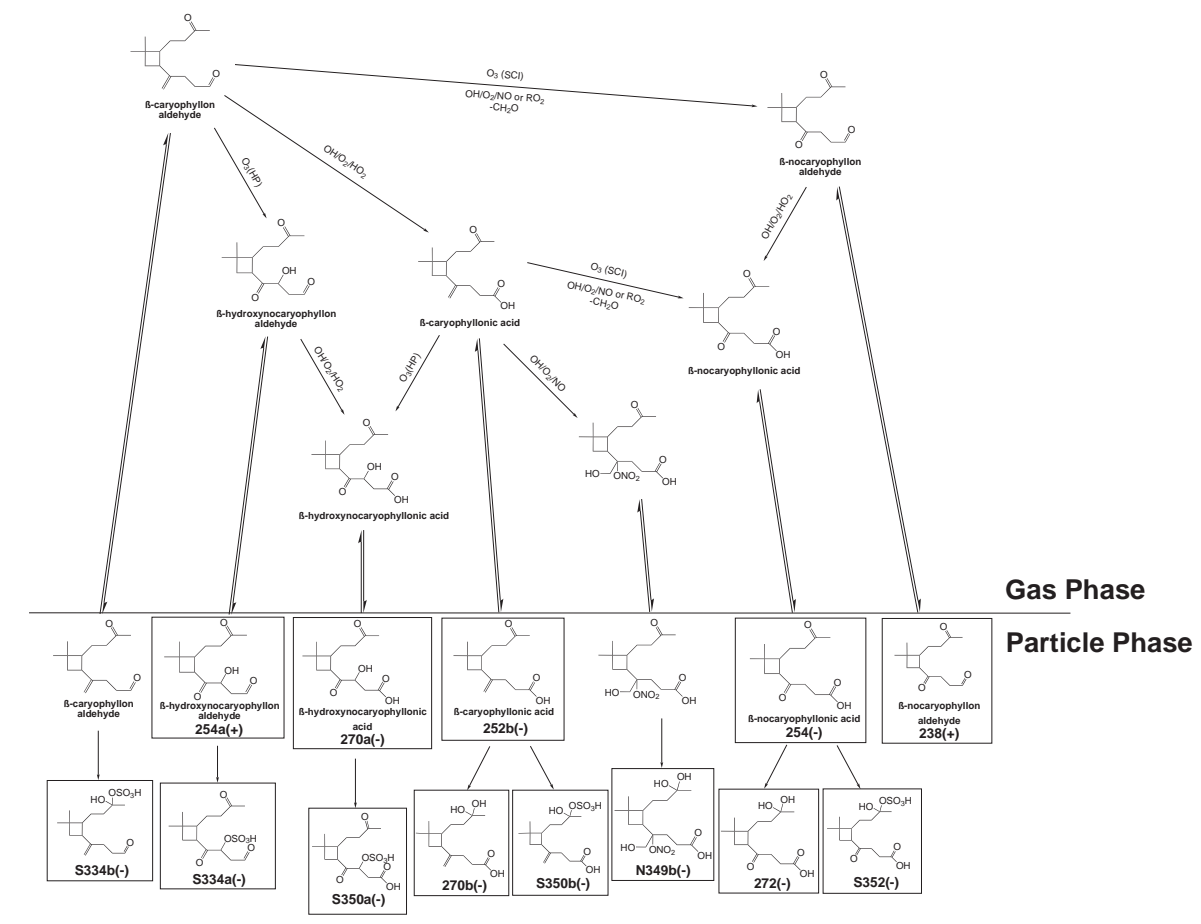

Scheme 2. Proposed reaction pathways of $\beta$-caryophyllon aldehyde, leading to compounds detected by ESI in the particle phase. Formation mechanism of $\beta$-caryophyllon aldehyde from the photooxidation and ozonolysis of $\beta$-caryophyllene (Lee et al., 2006b; Winterhalter et al., 2009). Boxes indicate compounds detected by ESI in the particle phase. One possible structural isomer is shown. SCI is the stabilized Criegee intermediates channel. HP is the hydroperoxide channel.

abstracted by $\mathrm{OH}$ to produce an acyl radical, which rapidly adds $\mathrm{O}_{2}$ to yield an acyl peroxy radical. The reaction of acyl peroxy radicals with $\mathrm{HO}_{2}$ forms carboxylic acid (Winterhalter et al., 2009). The acyl peroxy radicals can also react with $\mathrm{NO}$ and subsequently undergo decomposition or can react with $\mathrm{NO}_{2}$ in the presence of $\mathrm{NO}_{\mathrm{x}}$ to form peroxyacyl nitrates. The reaction of acyl peroxy radicals with $\mathrm{HO}_{2}$ to form carboxylic acid may explain the formation of acids detected in the particle phase. For example, acyl peroxy radicals formed from the aldehydic hydrogen abstraction of $\beta$-caryophyllon aldehyde can react with $\mathrm{HO}_{2}$ to form $\beta$-caryophyllonic acid (Scheme 2). However, it cannot be ruled out that the acids can form via other reaction pathways in the gas and particle phases. The $\mathrm{OH}$ abstraction of secondary or tertiary hydrogen may also occur (Jaoui et al., 2003) but is not considered here. Once the gas-phase products partition into the particle phase, they may undergo further chemical reactions. Reaction products formed via hydration and organosulfate formation have been detected in the particle phase, as discussed below.

\subsection{Particle-phase $\beta$-caryophyllene products detected by UPLC/ESI-TOFMS}

Tables 2-5 summarize the compounds detected by UPLC/ESI-TOFMS in both positive and negative ion modes in the series of $\beta$-caryophyllene/ $\mathrm{NO}_{\mathrm{x}}$ irradiation experiments. Proposed chemical structures are derived from accurate mass measurements, proposed reaction pathways, and previously identified chemical structures reported in the literature (Jaoui et al., 2003; Kanawati et al., 2008; Winterhalter et al., 2009; Li et al., 2011). Table 2 shows the compounds detected by ESI in the positive ion mode. Products having carbonyl groups can be ionized via proton attachment to form $[\mathrm{M}+\mathrm{H}]^{+}$ions and are detected in the positive ion mode (Kanawati et al., 2008). Adducts with sodium $[\mathrm{M}+\mathrm{Na}]^{+}$and with methanol + sodium $\left[\mathrm{M}+\mathrm{CH}_{3} \mathrm{OH}+\mathrm{Na}\right]^{+}$are used for redundant determination of the chemical formulas of the products ( $\mathrm{Li}$ et al., 2011). Recently, Parshintsev et al. (2008) have synthesized $\beta$ caryophyllene aldehyde and $\beta$-nocaryophyllone aldehyde. They reported that sodium adduct ions were the most abundant ions in their accurate mass measurements using ESI-TOF and could be used for identification and quantification of these two compounds in the aerosol samples by liquid chromatography-mass spectrometry. Firstgeneration products (e.g., $\beta$-hydroxycaryophyllon aldehyde) and second-generation products (e.g., $\beta$-nocaryophyllon aldehyde, $\beta$-hydroxynocaryophyllon aldehyde, and $\beta$ dihydroxynocaryophyllon aldehyde) are detected in the particle phase. 
Table 2. Compounds detected by ESI in the positive ion mode in the series of $\beta$-caryophyllene/ $\mathrm{NO}_{\mathrm{x}}$ irradiation experiments.

\begin{tabular}{|c|c|c|c|c|c|c|}
\hline $\begin{array}{l}\mathrm{ESI}(+) \\
\text { compound }\end{array}$ & $\begin{array}{l}\text { Suggested } \\
\text { chemical } \\
\text { formula }\end{array}$ & $\begin{array}{c}{[\mathrm{M}+\mathrm{H}]^{+}} \\
\text {(Theoretical } \\
\text { mass) }\end{array}$ & $\begin{array}{c}{[\mathrm{M}+\mathrm{Na}]^{+}} \\
\text {(Theoretical } \\
\text { mass) }\end{array}$ & $\begin{array}{c}{\left[\mathrm{M}+\mathrm{CH}_{3} \mathrm{OH}+\mathrm{Na}\right]^{+}} \\
\text {(Theoretical } \\
\text { mass) }\end{array}$ & $\begin{array}{l}\text { Suggested compound }{ }^{\text {a }} \\
\text { (Scheme) }\end{array}$ & $\begin{array}{l}\text { Proposed } \\
\text { chemical } \\
\text { structure }^{\text {b }}\end{array}$ \\
\hline $184(+)$ & $\mathrm{C}_{10} \mathrm{H}_{26} \mathrm{O}_{3}$ & $\begin{array}{l}\mathrm{C}_{10} \mathrm{H}_{27} \mathrm{O}_{3}^{+} \\
(185.1178)\end{array}$ & $\begin{array}{l}\mathrm{C}_{10} \mathrm{H}_{16} \mathrm{O}_{3} \mathrm{Na}^{+} \\
(207.0997)\end{array}$ & & & \\
\hline $238(+)$ & $\mathrm{C}_{14} \mathrm{H}_{22} \mathrm{O}_{3}$ & $\begin{array}{l}\mathrm{C}_{14} \mathrm{H}_{23} \mathrm{O}_{3}^{+} \\
(239.1647)\end{array}$ & $\begin{array}{r}\mathrm{C}_{14} \mathrm{H}_{22} \mathrm{O}_{3} \mathrm{Na}^{+} \\
(261.1467)\end{array}$ & $\begin{array}{r}\mathrm{C}_{15} \mathrm{H}_{26} \mathrm{O}_{4} \mathrm{Na}^{+} \\
(293.1729)\end{array}$ & $\begin{array}{l}\beta \text {-nocaryophyllon aldehyde } \\
\text { (2) }\end{array}$ & \\
\hline $250(+)$ & $\mathrm{C}_{15} \mathrm{H}_{22} \mathrm{O}_{3}$ & $\begin{array}{l}\mathrm{C}_{15} \mathrm{H}_{23} \mathrm{O}_{3}^{+} \\
(251.1647)\end{array}$ & $\begin{array}{l}\mathrm{C}_{15} \mathrm{H}_{22} \mathrm{O}_{3} \mathrm{Na}^{+} \\
(273.1467)\end{array}$ & & $\begin{array}{c}\beta \text {-oxocaryophyllon aldehyde } \\
\text { (4) }\end{array}$ & \\
\hline $252 \mathrm{a}(+)$ & $\mathrm{C}_{14} \mathrm{H}_{20} \mathrm{O}_{4}$ & $\begin{array}{l}\mathrm{C}_{14} \mathrm{H}_{21} \mathrm{O}_{4}^{+} \\
(253.1440)\end{array}$ & $\begin{array}{l}\mathrm{C}_{14} \mathrm{H}_{20} \mathrm{O}_{4} \mathrm{Na}^{+} \\
(275.1259)\end{array}$ & $\begin{array}{r}\mathrm{C}_{15} \mathrm{H}_{24} \mathrm{O}_{5} \mathrm{Na}^{+} \\
(307.1521)\end{array}$ & $\beta$-oxonocaryophyllon aldehyde & \\
\hline $252 \mathrm{~b}(+)$ & $\mathrm{C}_{15} \mathrm{H}_{24} \mathrm{O}_{3}$ & $\begin{array}{l}\mathrm{C}_{15} \mathrm{H}_{25} \mathrm{O}_{3}^{+} \\
(253.1804)\end{array}$ & & $\begin{array}{l}\mathrm{C}_{16} \mathrm{H}_{28} \mathrm{O}_{4} \mathrm{Na}^{+} \\
(307.1885)\end{array}$ & $\beta$-hydroxycaryophyllon aldehyde ${ }^{\mathrm{c}, \mathrm{d}, \mathrm{e}}$ & \\
\hline $\mathrm{N} 253(+)$ & $\mathrm{C}_{14} \mathrm{H}_{23} \mathrm{NO}_{3}$ & $\begin{array}{l}\mathrm{C}_{14} \mathrm{H}_{24} \mathrm{NO}_{3}^{+} \\
(254.1756)\end{array}$ & $\begin{array}{c}\mathrm{C}_{14} \mathrm{H}_{23} \mathrm{NO}_{3} \mathrm{Na}^{+} \\
(276.1576)\end{array}$ & & & \\
\hline $254 \mathrm{a}(+)$ & $\mathrm{C}_{14} \mathrm{H}_{22} \mathrm{O}_{4}$ & $\begin{array}{l}\mathrm{C}_{14} \mathrm{H}_{23} \mathrm{O}_{4}^{+} \\
(255.1596)\end{array}$ & $\begin{array}{r}\mathrm{C}_{14} \mathrm{H}_{22} \mathrm{O}_{4} \mathrm{Na}^{+} \\
(277.1416)\end{array}$ & $\begin{array}{r}\mathrm{C}_{15} \mathrm{H}_{26} \mathrm{O}_{5} \mathrm{Na}^{+} \\
(309.1678)\end{array}$ & $\begin{array}{c}\beta \text {-hydroxynocaryophyllon aldehyde } \mathrm{c}^{\mathrm{c}, \mathrm{e}} \\
(2,3)\end{array}$ & \\
\hline $254 \mathrm{~b}(+)$ & $\mathrm{C}_{15} \mathrm{H}_{26} \mathrm{O}_{3}$ & & $\begin{array}{l}\mathrm{C}_{15} \mathrm{H}_{26} \mathrm{O}_{3} \mathrm{Na}^{+} \\
(277.1780)\end{array}$ & & & \\
\hline $\mathrm{N} 267(+)$ & $\mathrm{C}_{15} \mathrm{H}_{25} \mathrm{NO}_{3}$ & $\begin{array}{l}\mathrm{C}_{15} \mathrm{H}_{26} \mathrm{NO}_{3}^{+} \\
(268.1913)\end{array}$ & $\begin{array}{l}\mathrm{C}_{15} \mathrm{H}_{25} \mathrm{NO}_{3} \mathrm{Na}^{+} \\
\quad(290.1732)\end{array}$ & & & \\
\hline $268(+)$ & $\mathrm{C}_{15} \mathrm{H}_{24} \mathrm{O}_{4}$ & $\begin{array}{l}\mathrm{C}_{15} \mathrm{H}_{25} \mathrm{O}_{4}^{+} \\
(269.1753)\end{array}$ & $\begin{array}{l}\mathrm{C}_{15} \mathrm{H}_{24} \mathrm{O}_{4} \mathrm{Na}^{+} \\
(291.1572)\end{array}$ & & & \\
\hline $270(+)$ & $\mathrm{C}_{14} \mathrm{H}_{22} \mathrm{O}_{5}$ & $\begin{array}{l}\mathrm{C}_{14} \mathrm{H}_{23} \mathrm{O}_{5}^{+} \\
(271.1545)\end{array}$ & $\begin{array}{c}\mathrm{C}_{14} \mathrm{H}_{22} \mathrm{O}_{5} \mathrm{Na}^{+} \\
(293.1365)\end{array}$ & $\begin{array}{l}\mathrm{C}_{14} \mathrm{H}_{26} \mathrm{O}_{6} \mathrm{Na}^{+} \\
(325.1627)\end{array}$ & $\beta$-dihydroxynocaryophyllon aldehyde ${ }^{c}$ (3) & \\
\hline $298(+)$ & $\mathrm{C}_{15} \mathrm{H}_{22} \mathrm{O}_{6}$ & $\begin{array}{l}\mathrm{C}_{15} \mathrm{H}_{23} \mathrm{O}_{6}^{+} \\
(299.1495)\end{array}$ & $\begin{array}{r}\mathrm{C}_{15} \mathrm{H}_{22} \mathrm{O}_{6} \mathrm{Na}^{+} \\
(321.1314)\end{array}$ & & & \\
\hline
\end{tabular}

Labels (+): compound detected by ESI in positive ion mode; (-): compound detected by ESI in negative ion mode; N: nitrogen-containing compound; S: sulfate esters or nitrooxy sulfate esters. Number represents the molecular weight of the compound. M is the compound. ${ }^{\text {a }}$ Terpene nomenclature, Larsen et al. (1998); ${ }^{b}$ only one possible isomer is shown for simplicity; ${ }^{\mathrm{c}}$ compound has been reported by Li et al. (2011); ${ }^{\mathrm{d}}$ compound has been reported by Winterhalter et al. (2009); ${ }^{\mathrm{e}}$ compound has been reported by Jaoui et al. (2003); $309(+)$ has been detected by the ESI in positive ion mode in this study, however, no reasonable chemical formula can be assigned.

Table 3 shows the compounds detected by ESI in negative ion mode. Products having a carboxylic acid group can be ionized via deprotonation and are detected in the negative ion mode as $[\mathrm{M}-\mathrm{H}]^{-}$ions. Several acids detected such as $\beta$-caryophyllonic acid, $\beta$-caryophyllinic acid, $\beta$-nocaryophyllonic acid, $\beta$-hydroxycaryophyllonic acid, $\beta$-hydroxynocaryophyllonic acid, and $\beta$-oxocaryophyllonic acid have been reported (Jaoui et al., 2003; Winterhalter et al., 2009; $\mathrm{Li}$ et al., 2011). Based on the accurate mass measurements and proposed reaction pathways, three new acids ( $\beta$-dihydroxycaryophyllonic acid, $\beta$-hydroxynornocaryophyllonic acid, and $\beta$ oxonocaryophyllonic acid) are tentatively identified in this study. $\beta$-caryophyllinic acid and $\beta$-nocaryophyllonic acid have the same chemical formula $\left(\mathrm{C}_{14} \mathrm{H}_{22} \mathrm{O}_{4}\right)$ and cannot be differentiated in the accurate mass measurements, especially since our study lacked authentic standards as well as tandem MS data. 
Table 3. Compounds detected by ESI in the negative ion mode in the series of $\beta$-caryophyllene/ $\mathrm{NO}_{\mathrm{x}}$ irradiation experiments.

\begin{tabular}{|c|c|c|c|c|c|c|}
\hline $\begin{array}{l}\text { ESI(-) } \\
\text { compound }\end{array}$ & {$[\mathrm{M}-\mathrm{H}]^{-}$} & $\begin{array}{l}\text { Suggested } \\
\text { chemical } \\
\text { formula }\end{array}$ & $\begin{array}{l}\text { Theoretical } \\
\text { mass }\end{array}$ & $\begin{array}{l}\text { Suggested compound }{ }^{\mathrm{a}} \\
\text { (Scheme) }\end{array}$ & $\begin{array}{l}\text { Proposed } \\
\text { chemical } \\
\text { structure }^{\mathrm{b}}\end{array}$ & $\begin{array}{c}\text { Detection of } \\
\text { dimer in ESI } \\
\text { negative ion } \\
\text { mode }\end{array}$ \\
\hline $186(-)$ & 185 & $\mathrm{C}_{9} \mathrm{H}_{13} \mathrm{O}_{4}^{-}$ & 185.0814 & & & \\
\hline $216(-)$ & 215 & $\mathrm{C}_{10} \mathrm{H}_{15} \mathrm{O}_{5}^{-}$ & 215.0919 & & & \\
\hline $252 \mathrm{a}(-)$ & 251 & $\mathrm{C}_{14} \mathrm{H}_{19} \mathrm{O}_{4}^{-}$ & 251.1283 & c & & \\
\hline $252 \mathrm{~b}(-)$ & 251 & $\mathrm{C}_{15} \mathrm{H}_{23} \mathrm{O}_{3}^{-}$ & 251.1647 & $\beta$-caryophyllonic acid (2) $)^{\mathrm{c}, \mathrm{d}, \mathrm{e}}$ & & $\mathrm{C}_{30} \mathrm{H}_{47} \mathrm{O}_{6}^{-}$ \\
\hline $254(-)$ & 253 & $\mathrm{C}_{14} \mathrm{H}_{21} \mathrm{O}_{4}^{-}$ & 253.1440 & $\begin{array}{c}\beta \text {-nocaryophyllonic acid (2) } \\
\beta \text {-caryophyllinic acid } \\
\mathrm{c}, \mathrm{d}, \mathrm{e}\end{array}$ & & $\mathrm{C}_{28} \mathrm{H}_{43} \mathrm{O}_{8}^{-}$ \\
\hline $256 \mathrm{a}(-)$ & 255 & $\mathrm{C}_{13} \mathrm{H}_{19} \mathrm{O}_{5}{ }^{-}$ & 255.1232 & $\beta$-hydroxynornocaryophyllonic acid (5) & & $\mathrm{C}_{26} \mathrm{H}_{39} \mathrm{O}_{10}^{-}$ \\
\hline $256 b(-)$ & 255 & $\mathrm{C}_{14} \mathrm{H}_{23} \mathrm{O}_{4}^{-}$ & 255.1596 & Hydrated $\beta$-norcaryophyllonic acid (5) & & \\
\hline $266(-)$ & 265 & $\mathrm{C}_{15} \mathrm{H}_{21} \mathrm{O}_{4}^{-}$ & 265.1440 & $\beta$-oxocaryophyllonic acid (4) ${ }^{\mathrm{e}}$ & & \\
\hline $268 \mathrm{a}(-)$ & 267 & $\mathrm{C}_{14} \mathrm{H}_{19} \mathrm{O}_{5}^{-}$ & 267.1232 & $\beta$-oxonocaryophyllonic acid (4) & & \\
\hline $268 b(-)$ & 267 & $\mathrm{C}_{15} \mathrm{H}_{23} \mathrm{O}_{4}^{-}$ & 267.1596 & $\beta$-hydroxycaryophyllonic acid (3) ${ }^{\mathrm{e}}$ & & \\
\hline $270 \mathrm{a}(-)$ & 269 & $\mathrm{C}_{14} \mathrm{H}_{21} \mathrm{O}_{5}^{-}$ & 269.1389 & $\beta$-hydroxynocaryophyllonic acid $(2,3)^{\mathrm{e}}$ & & $\mathrm{C}_{28} \mathrm{H}_{43} \mathrm{O}_{10}^{-}$ \\
\hline $270 \mathrm{~b}(-)$ & 269 & $\mathrm{C}_{15} \mathrm{H}_{25} \mathrm{O}_{4}^{-}$ & 269.1753 & Hydrated $\beta$-caryophyllonic acid (2) & & \\
\hline $272(-)$ & 271 & $\mathrm{C}_{14} \mathrm{H}_{23} \mathrm{O}_{5}^{-}$ & 271.1545 & Hydrated $\beta$-nocaryophyllonic acid (2) & & $\mathrm{C}_{28} \mathrm{H}_{47} \mathrm{O}_{10}^{-}$ \\
\hline $284(-)$ & 283 & $\mathrm{C}_{15} \mathrm{H}_{23} \mathrm{O}_{5}^{-}$ & 283.1545 & Hydrated $\beta$-oxocaryophyllonic acid (4) & & $\mathrm{C}_{30} \mathrm{H}_{47} \mathrm{O}_{10}{ }^{-}$ \\
\hline $286 \mathrm{a}(-)$ & 285 & $\mathrm{C}_{14} \mathrm{H}_{21} \mathrm{O}_{6}^{-}$ & 285.1338 & $\beta$-dihydroxynocaryophyllonic acid $(3,4)$ & & $\mathrm{C}_{28} \mathrm{H}_{43} \mathrm{O}_{12}^{-}$ \\
\hline $286 \mathrm{~b}(-)$ & 285 & $\mathrm{C}_{15} \mathrm{H}_{25} \mathrm{O}_{5}^{-}$ & 285.1702 & Hydrated $\beta$-hydroxycaryophyllonic acid (3) & & $\mathrm{C}_{30} \mathrm{H}_{51} \mathrm{O}_{10}^{-}$ \\
\hline
\end{tabular}


Table 3. Continued.

\begin{tabular}{|c|c|c|c|c|c|c|}
\hline $\begin{array}{l}\text { ESI(-) } \\
\text { compound }\end{array}$ & {$[\mathrm{M}-\mathrm{H}]-$} & $\begin{array}{c}\text { Suggested } \\
\text { chemical } \\
\text { formula }\end{array}$ & $\begin{array}{l}\text { Theoretical } \\
\text { mass }\end{array}$ & $\begin{array}{l}\text { Suggested compound a } \\
\text { (Scheme) }\end{array}$ & $\begin{array}{c}\text { Proposed } \\
\text { chemical } \\
\text { structure b }\end{array}$ & $\begin{array}{c}\text { Detection of } \\
\text { dimer in ESI } \\
\text { negative ion } \\
\text { mode }\end{array}$ \\
\hline $294(-)$ & 293 & $\mathrm{C}_{17} \mathrm{H}_{25} \mathrm{O}_{4}^{-}$ & 293.1753 & & & $\mathrm{C}_{34} \mathrm{H}_{51} \mathrm{O}_{8}^{-}$ \\
\hline $312(-)$ & 311 & $\mathrm{C}_{13} \mathrm{H}_{27} \mathrm{O}_{8}^{-}$ & 311.1706 & & & \\
\hline $314 a(-)$ & 313 & $\mathrm{C}_{15} \mathrm{H}_{21} \mathrm{O}_{7}^{-}$ & 313.1287 & & & \\
\hline $314 \mathrm{~b}(-)$ & 313 & $\mathrm{C}_{16} \mathrm{H}_{25} \mathrm{O}_{6}^{-}$ & 313.1651 & & & \\
\hline $320(-)$ & 319 & $\mathrm{C}_{14} \mathrm{H}_{23} \mathrm{O}_{8}^{-}$ & 319.1393 & & & \\
\hline $328(-)$ & 327 & $\mathrm{C}_{17} \mathrm{H}_{27} \mathrm{O}_{6}^{-}$ & 327.1808 & & & \\
\hline $330 a(-)$ & 329 & $\mathrm{C}_{16} \mathrm{H}_{25} \mathrm{O}_{7}^{-}$ & 329.1600 & & & \\
\hline $330 \mathrm{~b}(-)$ & 329 & $\mathrm{C}_{17} \mathrm{H}_{29} \mathrm{O}_{6}^{-}$ & 329.1964 & & & \\
\hline
\end{tabular}

a Terpene nomenclature, Larsen et al. (1998); ${ }^{\mathrm{b}}$ only one possible isomer is shown for simplicity; ${ }^{\mathrm{c}}$ compound has been reported by Li et al. (2011); ${ }^{\mathrm{d}}$ compound has been reported by Winterhalter et al. (2009); ${ }^{\mathrm{e}}$ compound has been reported by Jaoui et al. (2003).

$\beta$-caryophyllonic acid and $\beta$-caryophyllinic acid have traditionally been detected as first-generation products in the ozonolysis of $\beta$-caryophyllene. In the presence of $\mathrm{OH}$ and $\mathrm{NO}_{\mathrm{x}}, \beta$-caryophyllonic acid can form from the oxidation of $\beta$-caryophyllon aldehyde, which can form in the ozonolysis and photooxidation of $\beta$-caryophyllene (Scheme 2). $\beta$ caryophyllonic acid thus can be considered as either a firstor second-generation product. A number of other acids have been detected in this study. As shown in Schemes 2-5, many first- or higher-generation gas-phase products formed from the reaction of $\beta$-caryophyllene with $\mathrm{O}_{3}$ and $\mathrm{OH}$ have an aldehyde group. In the presence of $\mathrm{OH}$, the aldehydic hydrogen can be abstracted by $\mathrm{OH}$, leading to an acyl peroxy radical, which reacts with $\mathrm{HO}_{2}$ to give a carboxylic acid. This pathway could explain the formation of most of the organic acids observed in this study. However, it cannot be ruled out that the acids can form via other reaction pathways in the gas and particle phases. As shown in Tables 2 and 4, nitrogencontaining compounds have been detected by ESI in both positive and negative ion modes. The formation of nitrogencontaining compounds may attribute to the gas-phase reactions of peroxy radicals with NO; however, heterogeneous reaction processes in the particle phase (e.g., reactions between ammonia/ammonium ions with condensed gas-phase products containing carbonyl groups) cannot be completely ruled out (Nozière et al., 2009; Bones et al., 2010) and warrants future investigation.

Particle-phase reaction products formed via hydration and organosulfate formation of gas-phase products have been detected. Condensed gas-phase products can undergo hydrolysis in the particle phase. For example, a carbonyl group of $\beta$-hydroxycaryophyllonic acid could be hydrated into a diol (Scheme 3 ). The hydrated gas-phase products tend to have low volatility and are preferentially present in the particle phase. Compounds having molecular weights larger than 300 Da have been detected. It is likely that these compounds are esters, which can be detected by ESI due to their stability and ionization efficiency (Camredon et al., 2010). 
Table 4. Compounds detected by ESI in the negative ion mode in the series of $\beta$-caryophyllene/ $\mathrm{NO}_{\mathrm{x}}$ irradiation experiments (Nitrogencontaining compounds).

\begin{tabular}{|c|c|c|c|c|c|c|}
\hline $\begin{array}{l}\text { ESI(-) } \\
\text { compound }\end{array}$ & {$[\mathrm{M}-\mathrm{H}]^{-}$} & $\begin{array}{l}\text { Suggested } \\
\text { chemical } \\
\text { formula }\end{array}$ & $\begin{array}{l}\text { Theoretical } \\
\text { mass }\end{array}$ & $\begin{array}{l}\text { Suggested compound } \\
\text { (Scheme) }\end{array}$ & $\begin{array}{l}\text { Proposed } \\
\text { chemical } \\
\text { structure }^{\mathrm{a}}\end{array}$ & $\begin{array}{c}\text { Detection of } \\
\text { dimer in ESI } \\
\text { negative ion } \\
\text { mode }\end{array}$ \\
\hline N195(-) & 194 & $\mathrm{C}_{10} \mathrm{H}_{12} \mathrm{NO}_{3}^{-}$ & 194.0817 & & & $\mathrm{C}_{20} \mathrm{H}_{25} \mathrm{~N}_{2} \mathrm{O}_{6}^{-}$ \\
\hline N345(-) & 344 & $\mathrm{C}_{16} \mathrm{H}_{26} \mathrm{NO}_{7}^{-}$ & 344.1709 & & & \\
\hline N347(-) & 346 & $\mathrm{C}_{15} \mathrm{H}_{24} \mathrm{NO}_{8}^{-}$ & 346.1502 & (3) & & $\mathrm{C}_{30} \mathrm{H}_{49} \mathrm{~N}_{2} \mathrm{O}_{16}^{-}$ \\
\hline N349a(-) & 348 & $\mathrm{C}_{14} \mathrm{H}_{22} \mathrm{NO}_{9}^{-}$ & 348.1295 & & & $\mathrm{C}_{28} \mathrm{H}_{45} \mathrm{~N}_{2} \mathrm{O}_{18}{ }^{-}$ \\
\hline N349b(-) & 348 & $\mathrm{C}_{15} \mathrm{H}_{26} \mathrm{NO}_{8}^{-}$ & 348.1658 & (2) & & \\
\hline N350(-) & 349 & $\mathrm{C}_{13} \mathrm{H}_{21} \mathrm{~N}_{2} \mathrm{O}_{9}^{-}$ & 349.1247 & & & \\
\hline N363a(-) & 362 & $\mathrm{C}_{15} \mathrm{H}_{24} \mathrm{NO}_{9}{ }^{-}$ & 362.1451 & (4) & & $\mathrm{C}_{30} \mathrm{H}_{49} \mathrm{~N}_{2} \mathrm{O}_{18}^{-}$ \\
\hline N363b(-) & 362 & $\mathrm{C}_{16} \mathrm{H}_{28} \mathrm{NO}_{8}^{-}$ & 362.1815 & & & \\
\hline N375(-) & 374 & $\mathrm{C}_{17} \mathrm{H}_{28} \mathrm{NO}_{8}{ }^{-}$ & 374.1815 & & & \\
\hline N546(-) & 545 & $\mathrm{C}_{24} \mathrm{H}_{37} \mathrm{~N}_{2} \mathrm{O}_{12}^{-}$ & 545.2347 & & & $\begin{array}{l}\mathrm{C}_{12} \mathrm{H}_{18} \mathrm{NO}_{6}^{-} \\
\text {(Monomer) }\end{array}$ \\
\hline
\end{tabular}

a Only one possible isomer is shown for simplicity.

Several organosulfates, as well as two nitrated organosulfates, have been detected (Table 5). As shown in Schemes $1-5$, many gas-phase products contain hydroxyl groups, carbonyl groups, epoxide groups, or a combination of these groups. Organosulfates can possibly form from the particlephase esterification of sulfate ions with gas-phase products containing one or more hydroxyl groups; however, this reaction process has been shown to be kinetically infeasible for smaller alcohols at atmospherically relevant $\mathrm{pH}$ conditions (Minerath et al., 2008, 2009). Additionally, organosulfates can form from gas-phase products containing an aldehyde or a keto group. The reaction involves the electron pair of the carbonyl oxygen accepting a proton, producing the oxonium ion, and becoming susceptible to nucleophilic attack from a lone pair of electrons on one of the oxygen atoms of the sulfate ions (Surratt et al., 2007a, 2008). $\beta$-caryophyllene oxide can form in the ozonolysis of $\beta$-caryophyllene (Jaoui et al., 2003); this compound has been detected in a forested area in central Greece (Pio et al., 2001). Recent work has shown that organosulfates can form from the reactive uptake of epoxide intermediates (Minerath et al., 2009), such as those derived from isoprene (Cole-Filipiak et al., 2010; Eddingsaas et al., 2010; Surratt et al., 2010) or from $\alpha$ - and $\beta$-pinene (Iinuma et al., 2009). Reactive uptake of simple epoxides leading to organosulfates has been estimated to be kinetically feasible under atmospherically relevant $\mathrm{pH}$ conditions (Minerath et al., 2009; Cole-Filipiak et al., 2010, Eddingsaas et al., 2010). Similar to isoprene-derived epoxydiols and $\alpha$ - and $\beta$-pinene oxides, the sulfate ester of $\mathrm{m} / \mathrm{z} 317$ (Table 5) likely arises from the acid-catalyzed ring opening of $\beta$-caryophyllene oxide in the presence of acidic sulfate (Scheme 1). Most recently, organosulfates have also been shown to form from the irradiation of the aqueous-aerosol phase that contains sulfate (Galloway et al., 2009; Rudzinski et al., 2009; Nozière et al., 2010; Perri et al., 2010). The formation of organosulfates via sulfate radical reaction mechanisms may warrant further investigation. It is noted that isobaric organosulfates cannot be differentiated by the accurate mass measurements; 
Table 5. Compounds detected by ESI in the negative ion mode in the series of $\beta$-caryophyllene/ $\mathrm{NO}_{\mathrm{x}}$ irradiation experiments $($ Organosulfates).

\begin{tabular}{|c|c|c|c|c|c|}
\hline $\begin{array}{c}\text { ESI(-) } \\
\text { compound }\end{array}$ & {$[\mathrm{M}-\mathrm{H}]^{-}$} & $\begin{array}{l}\text { Suggested } \\
\text { chemical } \\
\text { formula }\end{array}$ & $\begin{array}{c}\text { Theoretical } \\
\text { mass }\end{array}$ & $\begin{array}{l}\text { Suggested } \\
\text { compound } \\
\text { (Scheme) }\end{array}$ & Proposed chemical structure ${ }^{a}$ \\
\hline S252(-) & 251 & $\mathrm{C}_{9} \mathrm{H}_{15} \mathrm{O}_{6} \mathrm{~S}^{-}$ & 251.0589 & & \\
\hline S304(-) & 303 & $\mathrm{C}_{14} \mathrm{H}_{23} \mathrm{O}_{5} \mathrm{~S}^{-}$ & 303.1266 & (1) & \\
\hline S318(-) & 317 & $\mathrm{C}_{15} \mathrm{H}_{25} \mathrm{O}_{5} \mathrm{~S}^{-}$ & 317.1423 & (1) & \\
\hline S320(-) & 319 & $\mathrm{C}_{14} \mathrm{H}_{23} \mathrm{O}_{6} \mathrm{~S}^{-}$ & 319.1215 & (1), (5) & \\
\hline S334a(-) & 333 & $\mathrm{C}_{14} \mathrm{H}_{21} \mathrm{O}_{7} \mathrm{~S}^{-}$ & 333.1008 & (2), (3) & \\
\hline S334b(-) & 333 & $\mathrm{C}_{15} \mathrm{H}_{25} \mathrm{O}_{6} \mathrm{~S}^{-}$ & 333.1372 & (2) & \\
\hline S348(-) & 347 & $\mathrm{C}_{15} \mathrm{H}_{23} \mathrm{O}_{7} \mathrm{~S}^{-}$ & 347.1165 & (3), (4) & \\
\hline S350a(-) & 349 & $\mathrm{C}_{14} \mathrm{H}_{21} \mathrm{O}_{8} \mathrm{~S}^{-}$ & 349.0957 & (2), (3), (4) & \\
\hline S350b(-) & 349 & $\mathrm{C}_{15} \mathrm{H}_{25} \mathrm{O}_{7} \mathrm{~S}^{-}$ & 349.1321 & (2), (3) & \\
\hline S352(-) & 351 & $\mathrm{C}_{14} \mathrm{H}_{23} \mathrm{O}_{8} \mathrm{~S}^{-}$ & 351.1114 & (2), (3) & \\
\hline S364a(-) & 363 & $\mathrm{C}_{15} \mathrm{H}_{23} \mathrm{O}_{8} \mathrm{~S}^{-}$ & 363.1114 & (4) & \\
\hline S364b(-) & 363 & $\mathrm{C}_{16} \mathrm{H}_{27} \mathrm{O}_{7} \mathrm{~S}^{-}$ & 363.1478 & & \\
\hline S380(-) & 379 & $\mathrm{C}_{16} \mathrm{H}_{27} \mathrm{O}_{8} \mathrm{~S}^{-}$ & 379.1427 & & \\
\hline
\end{tabular}

Nitrated Organosulfates

$\begin{array}{llll}\text { S363(-) } & 362 & \mathrm{C}_{15} \mathrm{H}_{24} \mathrm{NO}_{7} \mathrm{~S}^{-} & 362.1273 \\ \text { S383(-) } & 382 & \mathrm{C}_{14} \mathrm{H}_{24} \mathrm{NO}_{9} \mathrm{~S}^{-} & 382.1172\end{array}$

(1)

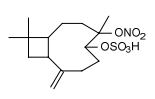

(1)

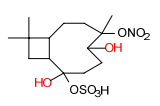




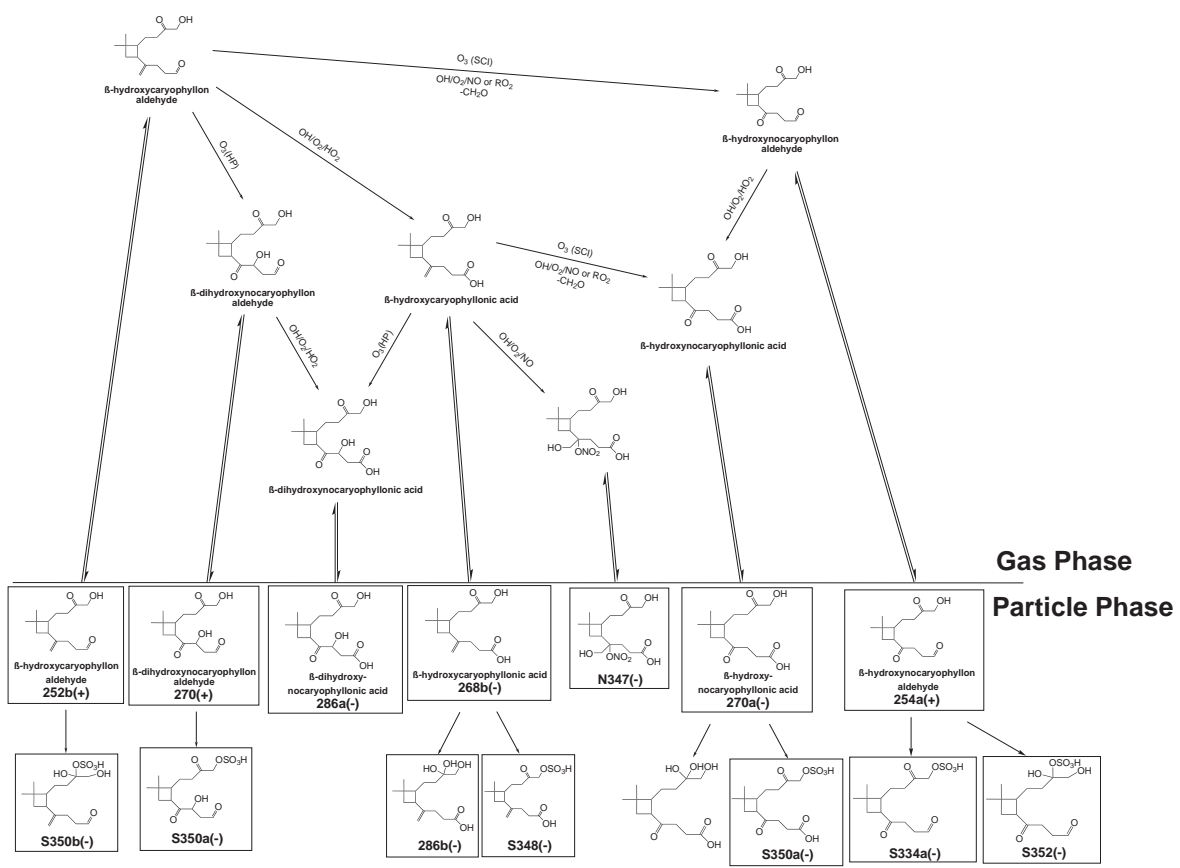

Scheme 3. Proposed reaction pathways of $\beta$-hydroxycaryophyllon aldehyde, leading to compounds detected by ESI in the particle phase. Formation mechanism of $\beta$-hydroxycaryophyllon aldehyde from the ozonolysis of $\beta$-caryophyllene (Winterhalter et al., 2009). $\beta$-14hydroxycaryophyllon aldehyde is chosen as illustration. Boxes indicate compounds detected by ESI in the particle phase. One possible structural isomer is shown. SCI is the stabilized Criegee intermediates channel. HP is the hydroperoxide channel.

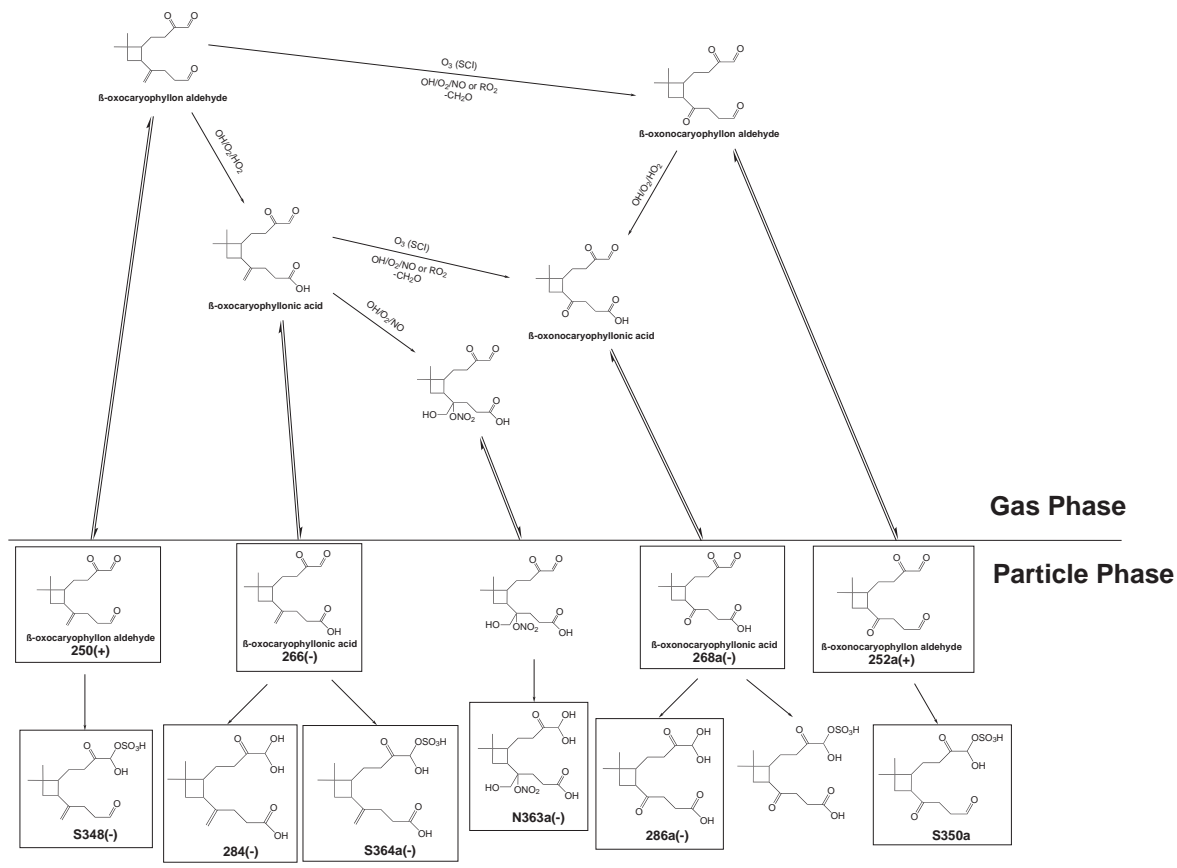

Scheme 4. Proposed reaction pathways of $\beta$-oxocaryophyllon aldehyde, leading to compounds detected by ESI in the particle phase. Formation mechanism of $\beta$-oxocaryophyllon aldehyde from the ozonolysis of $\beta$-caryophyllene (Winterhalter et al., 2009). $\beta$-14-oxocaryophyllon aldehyde is chosen as illustration. Boxes indicate compounds detected by ESI in the particle phase. One possible structural isomer is shown. $\mathrm{SCI}$ is the stabilized Criegee intermediates channel. 


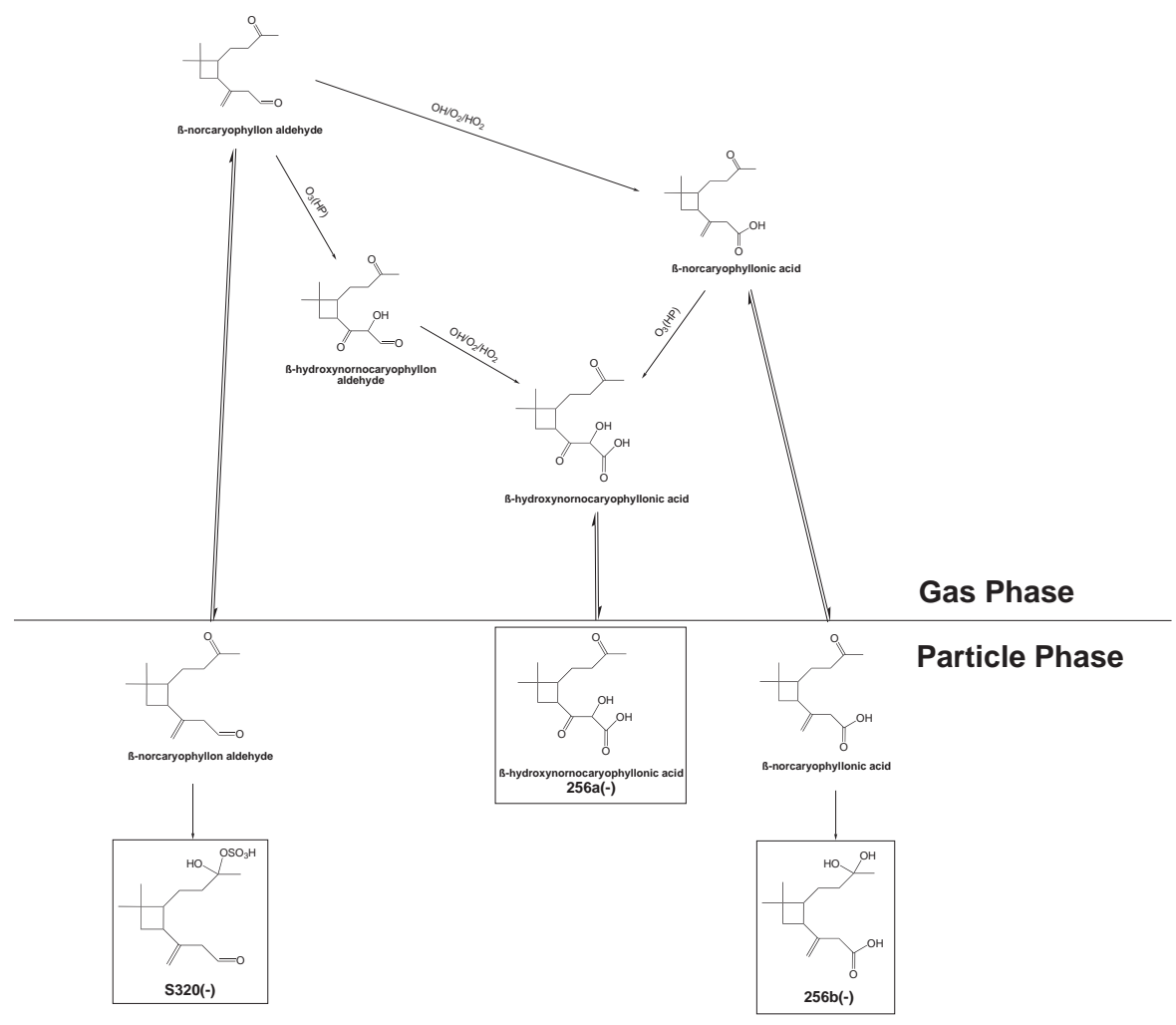

Scheme 5. Proposed reaction pathways of $\beta$-norcaryophyllon aldehyde, leading to compounds detected by ESI in the particle phase. Formation mechanism of $\beta$-norcaryophyllon aldehyde from the ozonolysis of $\beta$-caryophyllene (Winterhalter et al., 2009). Boxes indicate compounds detected by ESI in the particle phase. One possible structural isomer is shown. HP is the hydroperoxide channel.

however, further tandem MS studies, as well as synthesis of authentic standards, could elucidate these isobaric structures. Depending on the $\beta$-caryophyllene oxidation product (e.g., carbonyls or epoxides) formed, a number of chemical pathways may be leading to the formation of the organosulfates we observe.

Bonn and Moortgat (2003) and Li et al. (2011) have suggested that new particle formation can be initiated by very low volatile gas-phase products produced from $\beta$ caryophyllene ozonolysis. In the present study, some particle-phase products (first- or higher-generation products) form dimers in the mass spectra collected in the negative ion mode of ESI (e.g., for $\beta$-caryophyllonic acid (MW 252, $\left.\mathrm{C}_{15} \mathrm{H}_{24} \mathrm{O}_{3}\right)[2 \mathrm{M}-\mathrm{H}]^{-}$at $m / z 503\left(\mathrm{C}_{30} \mathrm{H}_{27} \mathrm{O}_{6}^{-}\right)$was detected). No dimer formation was observed for organosulfates despite relatively high signal intensity of these compounds. Although dimer formation could be potential artifacts of the ESI, the importance of dimer formation of $\beta$-caryophyllene gas-phase products to new particle formation can be noted and certainly warrants further investigation.

\subsection{Influence of aerosol acidity on the $\beta$-caryophyllene SOA composition}

In the series of $\beta$-caryophyllene/ $/ \mathrm{NO}_{\mathrm{x}}$ irradiation experiments, the aerosol acidity ranged from 112 to $1150 \mathrm{nmol}$ $\mathrm{H}^{+} \mathrm{m}^{-3}$ and SOA concentrations ranged from 9.97 to $34.0 \mu \mathrm{g} \mathrm{m}^{-3}$. Higher SOA concentrations were measured in the presence of increased aerosol acidity. For comparison, field measurements of aerosol acidity as $\left[\mathrm{H}^{+}\right]_{\text {air }}$ have been reported (e.g., Liu et al., 1996; Pathak et al., 2003, 2004; Surratt et al., 2007b). The $\left[\mathrm{H}^{+}\right]_{\text {air }}$ generally ranged from about 20 to $130 \mathrm{nmol} \mathrm{H}^{+} \mathrm{m}^{-3}$. Aerosol acidities have also been observed to exceed $300 \mathrm{nmol}$ of $\mathrm{H}^{+} \mathrm{m}^{-3}$ during episodes of high photochemical activity in the eastern US. For example, Liu et al. (1996) observed an aerosol acidity of up to $400 \mathrm{nmol}$ of $\mathrm{H}^{+} \mathrm{m}^{-3}$ in particles collected from Uniontown, PA. Since changes in the aerosol acidity in the present study had no significant direct effect on the gas-phase chemistry in these series of experiments (Offenberg et al., 2009), changes in the composition of $\beta$-caryophyllene SOA at different acidities is likely attributed to the particle-phase reactions. Figures 1-5 show the concentrations of compounds detected by ESI in both positive and negative ion modes in the series of $\beta$-caryophyllene/ $\mathrm{NO}_{\mathrm{x}}$ irradiation experiments. Different 
effects of acidity on the abundance of individual compounds have been observed. For gas-phase products (Figs. 1-3) and nitrogen-containing compounds (Fig. 4) detected, some compounds (e.g., $\beta$-hydroxynocaryophyllon aldehyde, $\beta$ dihydroxynocaryophyllon aldehyde, $\beta$-oxonocaryophyllonic acid, and $\beta$-hydroxynocaryophyllonic acid) show an increase with increasing aerosol acidity, while other compounds (e.g., $\beta$-nocaryophyllon aldehyde, $\beta$-hydroxycaryophyllon aldehyde, $\beta$-caryophyllonic acid, and $\beta$-hydroxycaryophyllonic acid) exhibit a decrease at higher aerosol acidity. It is also seen that acidity has no significant effect on the concentration of some compounds (e.g., $\beta$-hydroxynornocaryophyllonic acid and $\beta$-dihydroxynocaryophyllonic acid).

For particle-phase reaction products, many hydrated compounds are detected at low aerosol acidity, while a few hydrated compounds (e.g., hydrated $\beta$-caryophyllonic acid and hydrated $\beta$-norcaryophyllonic acid) are detected only at higher aerosol acidity. The concentrations of many, but not all, hydrated compounds are found to increase with increasing aerosol acidity. By contrast, hydrated $\beta$ nocaryophyllonic acid has a lower concentration at higher aerosol acidity. Different effects of aerosol acidity on the concentration of high molecular weight compounds $(\mathrm{MW}>300 \mathrm{Da})$ are observed. Figure 5 shows that the concentration of organosulfates and nitrated organosulfates generally increases with increasing aerosol acidity, except $\mathrm{m} / \mathrm{z}$ 349 and 363. The concentrations of some organosulfates increase substantially with the aerosol acidity. For example, the signal intensities for $m / z 317$ and 347 increase by a factor of $\sim 8$ at the highest aerosol acidity, as compared to the lowest aerosol acidity. Also, a larger array of organosulfates is detected under higher acidic conditions. The aerosol acidity and sulfate content determine not only the concentration of organosulfates but also the kinds of organosulfates formed. To our knowledge, this is the first detection of organosulfates and nitrated organosulfates derived from a sesquiterpene.

Although the mechanisms by which acidity affects the concentrations of individual compounds are not well understood, some observations can be made. It is found that not all particle-phase concentrations of gas-phase products increase with increasing aerosol acidity. Although gas/particle equilibrium shifts further toward the particle phase due to enhanced particle-phase reactions, the condensed gas-phase products can, as a result, react in the particle phase to form other products (e.g., hydrated compounds and sulfate esters) at an accelerated rate under acidic conditions. Because such reactions serve to convert the specific partitioning species to another compound, the enhanced gas/particle equilibrium does necessarily lead to an increase in the particle-phase concentration of gas-phase products. Although an increase in gas/particle partitioning coefficients of gas-phase products may help to capture the acid-enhanced SOA formation in a model (Kroll and Seinfeld, 2005), increased acidity does not always lead to an increase in the particle-phase concentration of gas-phase products.

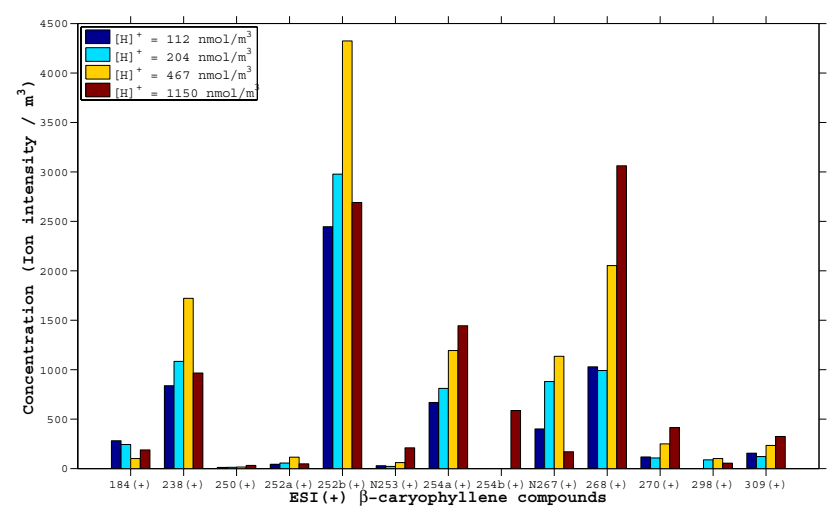

Fig. 1. Concentration of compounds detected by ESI in positive ion mode in the series of $\beta$-caryophyllene/ $/ \mathrm{NO}_{\mathrm{x}}$ irradiation experiments. Chemical formulas and proposed chemical structures of these compounds are given in Table 2.

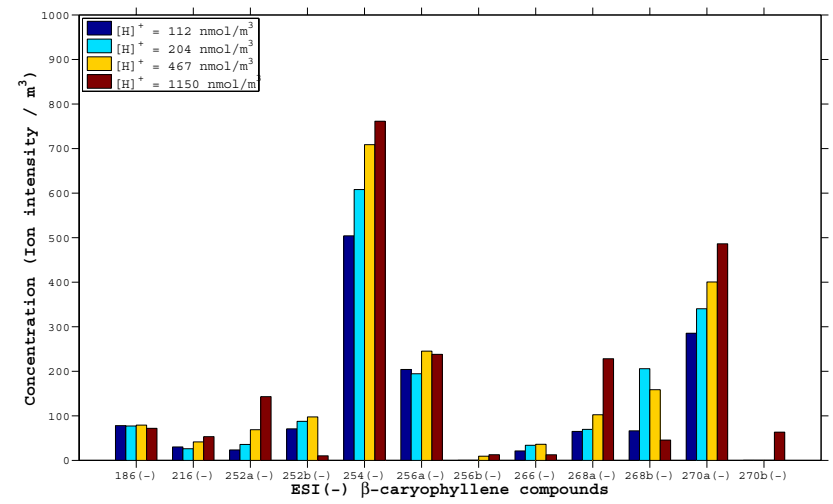

Fig. 2. Concentration of compounds detected by ESI in negative ion mode in the series of $\beta$-caryophyllene/ $/ \mathrm{NO}_{\mathrm{x}}$ irradiation experiments. Chemical formulas and proposed chemical structures of these compounds are given in Table 3.

The concentrations of particle-phase reaction products formed via acid-catalyzed reactions are expected to increase with increasing aerosol acidity. However, a few hydrated gas-phase products and some higher molecular weight compounds have a lower concentration at higher aerosol acidity. It is possible that other chemical reactions (e.g., organosulfate formation processes) may become kinetically more favorable and competitive at higher aerosol acidity. Due to the complexity of chemical reactions that can potentially occur among the compounds in the particle phase, it may not be surprising to see that the acidity exhibits different effects on the concentration of particle-phase reaction products at different acidities and not all classes of particle-phase reaction products have a higher concentration at higher acidity.

Overall, increased acidity exhibits different effects on the abundance of individual compounds and does not always enhance the concentration of gas-phase and particle-phase 


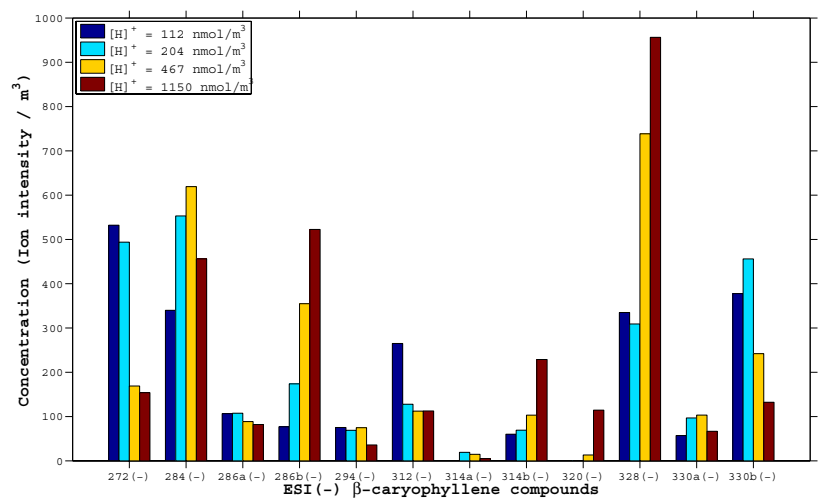

Fig. 3. Concentration of compounds detected by ESI in negative ion mode in the series of $\beta$-caryophyllene $/ \mathrm{NO}_{\mathrm{x}}$ irradiation experiments. Chemical formulas and proposed chemical structures of these compounds are given in Table 3.

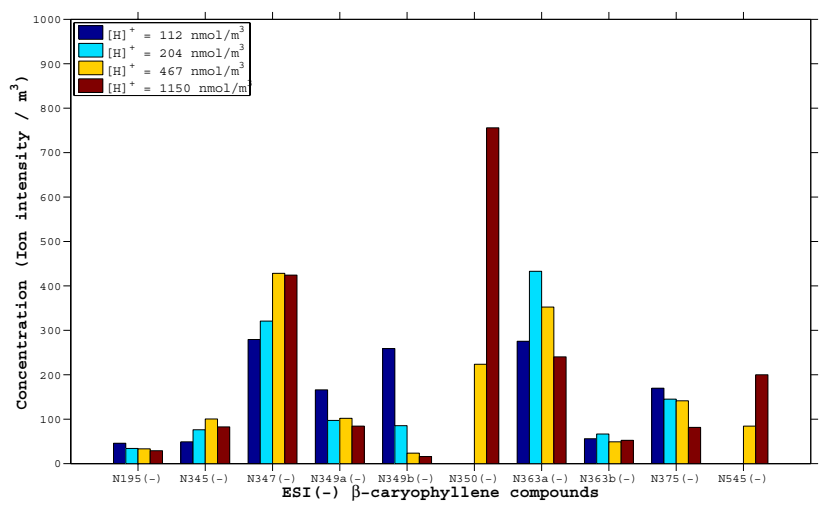

Fig. 4. Concentration of compounds detected by ESI in negative ion mode in the series of $\beta$-caryophyllene/ $\mathrm{NO}_{\mathrm{x}}$ irradiation experiments (nitrogen-containing compounds). Chemical formulas and proposed chemical structures of these compounds are given in Table 4 .

reaction products. Varying acidity also changes the product distribution. Although qualitative data are obtained for the concentrations, the relative increase in concentration of many gas-phase and particle-phase reaction products provides chemical evidence for the acid enhanced SOA formation from $\beta$-caryophyllene $/ \mathrm{NO}_{\mathrm{x}}$ irradiation experiments.

\section{Atmospheric implications}

Chemical characterization of particle-phase products in the chamber samples can suggest possible chemical tracers for SOA formation from $\beta$-caryophyllene in ambient aerosol. Fine ambient aerosol collected in downtown Atlanta, GA (JST) and rural Yorkville, GA (YRK) during the AMIGAS campaign was analyzed for the presence of $\beta$-caryophyllene SOA constituents characterized from the laboratory stud-

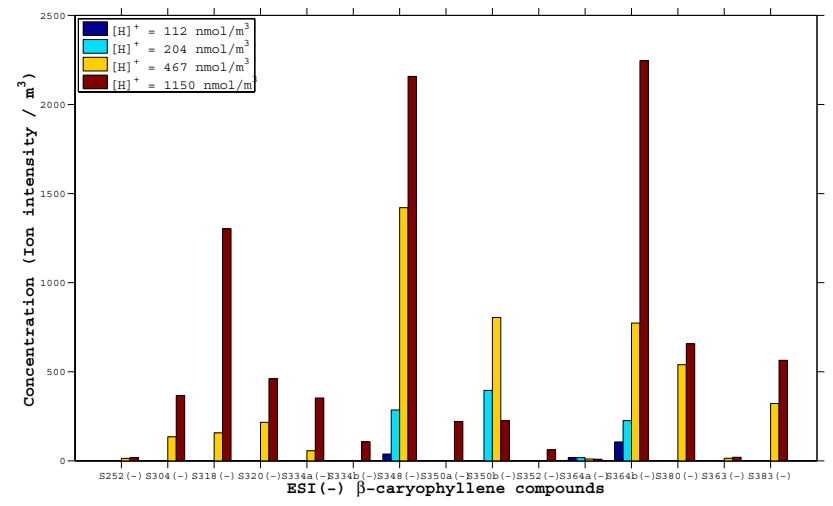

Fig. 5. Concentration of compounds detected by ESI in negative ion mode in the series of $\beta$-caryophyllene/ $\mathrm{NO}_{\mathrm{x}}$ irradiation experiments (organosulfates and nitrated organosulfates). Chemical formulas and proposed chemical structures of these compounds are given in Table 5 .

ies. As shown in Table S1, the retention time and accurate mass measurements match very well for four ions detected in both ambient and chamber samples by ESI in the positive ion mode. Three of these compounds have been tentatively identified in the present study and are $\beta$ nocaryophyllon aldehyde, $\beta$-hydroxynocaryophyllon aldehyde, and $\beta$-dihydroxynocaryophyllon aldehyde. Each of these three compounds is a second-generation ozonolysis product previously identified in $\beta$-caryophyllene ozonolysis (Li et al., 2011). As shown in Schemes 2-4, these compounds can also be produced from the reaction of $\beta$ caryophyllene with a combination of $\mathrm{O}_{3}$ and $\mathrm{OH}$. The chemical structure of the compound $\left(\mathrm{C}_{15} \mathrm{H}_{24} \mathrm{O}_{4}\right)$ is not known yet. Although the emission of $\beta$-caryophyllene drops sharply at night (Sakulyanontvittaya et al., 2008), all these compounds have been detected in most day and night samples at both sites. As shown in Table S1, based on the limited sample sizes, $\beta$-nocaryophyllon aldehyde showed a higher concentration in the nighttime samples at both JST and YRK sites. No strong diurnal variation in the concentrations was observed for the other compounds. Recently, Parshintsev et al. (2008) reported that $\beta$-nocaryophyllon aldehyde was present in ambient aerosol collected during spring 2003 at Hyytiälä, Finland. $\beta$-caryophyllon aldehyde was not detected in their ambient samples.

Gas/particle partitioning coefficients of the three aldehydes, $K_{\mathrm{p}}\left(\mathrm{m}^{3} \mu \mathrm{g}^{-1}\right)$, are estimated at $297 \mathrm{~K}$ (Pankow, 1994). As a first approximation, the activity coefficients of the products in the particle phase are assumed to be unity and the molecular weight of the products is used as mean molecular weight in the absorbing phase. Vapor pressures are estimated at $297 \mathrm{~K}$ using the model developed by Pankow and Asher (2008). Saturation vapor pressure, $c^{*}$ is inversely proportional to $K_{\mathrm{p}}\left(c^{*} \sim 1 / K_{\mathrm{p}}\right)$. The fraction $F$ of a semivolatile compound in the particle phase can be expressed 
in term of $K_{\mathrm{p}}$ as $F=M K_{\mathrm{p}} /\left(1+M K_{\mathrm{p}}\right)$, where $M$ is the amount of absorbing material $\left(\mu \mathrm{g} \mathrm{m}^{-3}\right)$. Based on estimated gas/particle partitioning coefficients of $\beta$-nocaryophyllon aldehyde $\left(K_{\mathrm{p}}=2.5 \times 10^{-3} \mathrm{~m}^{3} \mu \mathrm{g}^{-1} ; c^{*}=400 \mu \mathrm{g} \mathrm{m}^{-3}\right)$, $\beta$-hydroxynocaryophyllon aldehyde $\left(K_{\mathrm{p}}=0.37 \mathrm{~m}^{3} \mu \mathrm{g}^{-1}\right.$; $\left.c^{*}=2.7 \mu \mathrm{g} \mathrm{m}^{-3}\right)$, and $\beta$-dihydroxynocaryophyllon aldehyde $\left(K_{\mathrm{p}}=54 \mathrm{~m}^{3} \mu \mathrm{g}^{-1} ; c^{*}=0.018 \mu \mathrm{g} \mathrm{m}^{-3}\right)$, a significant fraction of $\beta$-hydroxynocaryophyllon aldehyde $(F=0.787)$ and $\beta$ dihydroxynocaryophyllon aldehyde $(F=0.998)$ is present in the particle phase under typical organic mass loading $(M \sim$ $\left.10 \mu \mathrm{g} \mathrm{m}^{-3}\right)$. A small portion of $\beta$-nocaryophyllon aldehyde $(F=0.024)$ can partition into the particle phase. The estimated saturated vapor pressures of these compounds in the present work are lower by a factor of about 2-40 than those estimated by Li et al. (2011) using a different vapor pressure estimation model.

Organosulfates detected in the laboratory-generated $\beta$ caryophyllene SOA were not observed in the ambient samples collected from the AMIGAS campaign. It is possible that the acidity of ambient aerosol is not strong enough for the formation of $\beta$-caryophyllene-derived organosulfates. As shown in Fig. 5, most organosulfates detected in the chamber samples require high aerosol acidity (467$1150 \mathrm{nmol} \mathrm{H}^{+} \mathrm{m}^{-3}$ ). It is worth noting that isoprene-derived organosulfates (e.g., organosulfates of 2-methyltetrols) have been detected in these AMIGAS ambient samples (Chan et al., 2010), which were also detected in laboratory-generated isoprene SOA that employed a lower $\left[\mathrm{H}^{+}\right]_{\text {air }}$ that lied between $275-517 \mathrm{nmol} \mathrm{m}^{-3}$ (Surratt et al., 2007b). Although accurate mass measurements obtained in the negative ion mode show that similar molecular ions were detected in both the AMIGAS and chamber samples for some $\beta$-caryophyllene-derived acids, the chromatographic peaks of these ions in the AMIGAS samples elute at different retention times $(\mathrm{RT})(\Delta \mathrm{RT}>0.2 \mathrm{~min})$ and may not correspond to those of the chamber samples, especially since our study lacked authentic standards and tandem MS data. The detection of $\beta$-caryophyllinic acid in ambient samples is also complicated by $\beta$-nocaryophyllonic acid. $\beta$-caryophyllinic acid and $\beta$-nocaryophyllonic acid have the same chemical formula $\left(\mathrm{C}_{14} \mathrm{H}_{22} \mathrm{O}_{4}\right)$ and cannot be differentiated in the accurate mass measurements.

Overall, the presence of $\beta$-caryophyllene products in ambient aerosol has been confirmed based on the agreement of chromatographic retention times and accurate mass measurements between chamber and field samples. These results suggest that the presence of $\beta$ caryophyllene products in biogenic SOA can be used as an indication of its contribution to SOA. $\beta$-nocaryophyllon aldehyde, $\beta$-hydroxynocaryophyllon aldehyde, and $\beta$ dihydroxynocaryophyllon aldehyde may be good candidates for $\beta$-caryophyllene SOA tracers.

\section{Supplementary material related to this article is available online at: http://www.atmos-chem-phys.net/11/1735/2011/ acp-11-1735-2011-supplement.pdf.}

Acknowledgements. This work was supported by the Electric Power Research Institute and the Southern Company, Birmingham, AL. We acknowledge all members of the AMIGAS for their support during the field campaign. The US Environmental Protection Agency through its Office of Research and Development funded and collaborated in the research described here under Contract 68-D-00-206 to Alion Science and Technology. It has been subject to Agency review and approved for publication. Mention of trade names or commercial products does not constitute an endorsement or recommendation for use.

Edited by: H. Saathoff

\section{References}

Bones, D. L., Henricksen, D. K., Mang, S. A., Gonsior, M., Bateman, A. P., Nguyen, T. B., Cooper, W. J., and Sergey Nizkorodov, S. A.: Appearance of strong absorbers and fluorophores in limonene-O3 secondary organic aerosol due to $\mathrm{NH}_{4}^{+}$-mediated chemical aging over long time scales, J. Geophys. Res., 115, D05203, doi:10.1029/2009JD012864, 2010.

Bonn, B. and Moortgat, G. K.: Sesquiterpene ozonolysis: Origin of atmospheric new particle formation from biogenic hydrocarbons, Geophys. Res. Lett., 30(11), 1585, doi:10.1029/2003GL017000, 2003.

Calogirou, A., Kotzias, D., and Kettrup, A.: Product analysis of the gas-phase reaction of beta-caryophyllene with ozone, Atmos. Environ., 31, 283-285, 1997.

Camredon, M., Hamilton, J. F., Alam, M. S., Wyche, K. P., Carr, T., White, I. R., Monks, P. S., Rickard, A. R., and Bloss, W. J.: Distribution of gaseous and particulate organic composition during dark $\alpha$-pinene ozonolysis, Atmos. Chem. Phys., 10, 2893-2917, doi:10.5194/acp-10-2893-2010, 2010.

Chan, M. N., Surratt, J. D., Claeys, M., Edgerton, E. S., Tanner, R L., Shaw, S. L., Zheng, M., Knipping, E. M., Eddingsaas, N. C., Wennberg, P. O., and Seinfeld, J. H.: Characterization and quantification of isoprene-derived epoxydiols in ambient aerosol in the southeastern United States, Environ. Sci. Technol., 44, 4590 4596, 2010.

Cole-Filipiak, N. C., O'Connor, A. E., and Elrod, M. J.: Kinetics of the hydrolysis of atmospherically relevant isoprene-derived hydroxy epoxides, Environ. Sci. Technol., 44, 6718-6723, 2010.

Eddingsaas, N. C., VanderVelde, D. G., and Wennberg, P. O.: Kinetics and products of the acid-catalyzed ring-opening of atmospherically relevant butyl epoxy alcohols, J. Phys. Chem. A, 114, 8106-8113, 2010.

Galloway, M. M., Chhabra, P. S., Chan, A. W. H., Surratt, J. D., Flagan, R. C., Seinfeld, J. H., and Keutsch, F. N.: Glyoxal uptake on ammonium sulphate seed aerosol: reaction products and reversibility of uptake under dark and irradiated conditions, Atmos. Chem. Phys., 9, 3331-3345, doi:10.5194/acp-9-3331-2009, 2009. 
Griffin, R. J., Cocker, D. R., Flagan, R. C., and Seinfeld, J. H.: Organic aerosol formation from the oxidation of biogenic hydrocarbons, J. Geophys. Res., 104, 3555-3567,1999.

Hallquist, M., Wenger, J. C., Baltensperger, U., Rudich, Y., Simpson, D., Claeys, M., Dommen, J., Donahue, N. M., George, C., Goldstein, A. H., Hamilton, J. F., Herrmann, H., Hoffmann, T., Iinuma, Y., Jang, M., Jenkin, M. E., Jimenez, J. L., Kiendler-Scharr, A., Maenhaut, W., McFiggans, G., Mentel, Th. F., Monod, A., Prévôt, A. S. H., Seinfeld, J. H., Surratt, J. D., Szmigielski, R., and Wildt, J.: The formation, properties and impact of secondary organic aerosol: current and emerging issues, Atmos. Chem. Phys., 9, 5155-5236, doi:10.5194/acp-95155-2009, 2009.

Iinuma, Y., Müller, C., Berndt, T., Böge, O., Claeys, M., and Herrmann, H.: Evidence for the existence of organosulfates from beta-pinene ozonolysis in ambient secondary organic aerosol, Environ. Sci. Technol., 41, 6678-6683, 2007.

Iinuma, Y., Böge, O., Kahnt, A., and Herrmann, H.: Laboratory chamber studies on the formation of organosulfates from reactive uptake of monoterpene oxides, Phys. Chem. Chem. Phys., 11, 7985-7997, 2009.

Jang, M., Czoschke, N. M., Lee, S., and Kamens, R. M.: Heterogeneous atmospheric aerosol production by acid-catalyzed particle phase reactions, Science, 298, 814-817, 2002.

Jaoui, M., Leungsakul, S., and Kamens, R. M.: Gas and particle products distribution from the reaction of beta-caryophyllene with ozone, J. Atmos. Chem., 45, 261-287, 2003.

Jaoui, M., Lewandowski, M., Kleindienst, T. E., Offenberg, J. H., and Edney, E. O.: Beta-caryophyllinic acid: An atmospheric tracer for beta-caryophyllene secondary organic aerosol, Geophys. Res. Lett., 34, L05816, doi:10.1029/2006GL028827, 2007.

Kanawati, B., Herrmann, F., Joniec, S., Winterhalter, R., and Moortgat, G. K.: Mass spectrometric characterization of bcaryophyllene ozonolysis products in the aerosol studied using an electrospray triple quadrupole and time-of-flight analyzer hybrid system and density functional theory, Rapid Commun. Mass Spectrom., 22, 165-186, 2008.

Kleindienst, T. E., Jaoui, M., Lewandowski, M., Offenberg, J. H., Lewis, C. W., Bhave, P. V., and Edney, E. O.: Estimates of the contributions of biogenic and anthropogenic hydrocarbons to secondary organic aerosol at a southeastern US location, Atmos. Environ., 41, 8288-8300, 2007.

Kroll, J. H. and Seinfeld, J. H.: Representation of secondary organic aerosol laboratory chamber data for the interpretation of mechanisms of particle growth, Environ. Sci. Technol., 39, 4159-4165, 2005.

Kroll, J. H. and Seinfeld, J. H.: Chemistry of secondary organic aerosol: Formation and evolution of low-volatility organics in the atmosphere, Atmos. Environ., 42, 3593-3624, 2008.

Larsen, B. R., Lahaniati, M., Calogirou, A., and Kotzias, D.: Atmospheric oxidation products of terpenes: a new nomenclature, Chemosphere, 37, 1207-1220, 1998.

Lee, A., Goldstein, A. H., Keywood, M. D., Gao, S., Varutbangkul, V., Bahreini, R., Ng, N. L., Flagan, R. C., and Seinfeld, J. H.: Gas-phase products and secondary aerosol yields from the ozonolysis of ten different terpenes, J. Geophys. Res., 111(D7), D07302, doi:10.1029/2005JD006437, 2006a.

Lee, A., Goldstein, A. H., Kroll, J. H., Ng, N. L., Varutbangkul, V., Flagan, R. C., and Seinfeld, J. H: Gas-phase prod- ucts and secondary aerosol yields from the photooxidation of 16 different terpenes, J. Geophys. Res., 111(D17), D17305, doi:10.1029/2006JD007050, 2006b.

Lewandowski, M., Jaoui, M., Offenberg, J. H., Kleindienst, T. E., Edney, E. O., Sheesley, R. J., and Schauer, J. J.: Primary and secondary contributions to ambient PM in Midwestern United States, Environ. Sci. Technol., 42, 3303-3309, 2008.

Li, Y. J., Chen, Q., Guzman, M. I., Chan, C. K., and Martin, S. T.: Second-generation products contribute substantially to the particle-phase organic material produced by $\beta$-caryophyllene ozonolysis, Atmos. Chem. Phys., 11, 121-132, doi:10.5194/acp11-121-2011, 2011.

Liggio, J. and Li, S. M.: Organosulfate formation during the uptake of pinonaldehyde on acidic sulfate aerosols, Geophys. Res. Lett., 33(13), L13808, 10.1029/2006GL026079, 2006.

Liu, L.-J. S., Burton, R., Wilson, W. E., and Koutrakis, P.: Comparison of aerosol acidity in urban and semirural environments, Atmos. Environ., 30, 1237-1245, 1996.

Minerath, E. C., Casale, M. T., and Elrod, M. J.: Kinetics feasibility study of alcohol sulfate esterification reactions in tropospheric aerosols, Environ. Sci. Technol., 42, 4410-4415, 2008.

Minerath, E. C., Schultz, M. P., and Elrdo, M. J.: Kinetics of the reactions of isoprene-derived epoxides in model tropospheric aerosol solutions, Environ. Sci. Technol., 43, 8133-8139, 2009.

Ng, N. L., Kroll, J. H., Keywood, M. D., Bahreini, R., Varutbangkul, V., Flagan, R. C., Seinfeld, J. H., Lee, A., and Goldstein, A. H.: Contribution of first- versus second-generation products to secondary organic aerosols formed in the oxidation of biogenic hydrocarbons, Environ. Sci. Technol., 40, 2283-2297, 2006.

Nguyen, T. L., Winterhalter, R., Moortgat, G., Kanawati, B., Peeters, J., and Vereecken, L.: The gas-phase ozonolysis of beta-caryophyllene $\left(\mathrm{C}_{15} \mathrm{H}_{24}\right)$, Part 2: A theoretical study, Phys. Chem. Chem. Phys., 11, 4173-4183, 2009.

Nozière, B., Dziedzic, P., and Córdova, A.: Products and kinetics of the liquid-phase reaction of glyoxal catalyzed by ammonium Ions $\left(\mathrm{NH}_{4}^{+}\right)$, J. Phys. Chem. A, 113, 231-237, 2009.

Nozière, B., Ekstrom, S., Alsberg, T., and Holmstrom, S.: Radical-initiated formation of organosulfates and surfactants in atmospheric aerosols, Geophys. Res. Lett., 37, L05806, doi:10.1029/2009GL041683, 2010.

Offenberg, J. H., Lewandowski, M., Edney, E. O., Kleindienst, T. E., and Jaoui, M.: Influence of aerosol acidity on the formation of secondary organic aerosol from biogenic precursor hydrocarbons, Environ. Sci. Technol., 43, 7742-7747, 2009.

Pankow, J. F.: An absorption model of the gas aerosol partitioning involved in the formation of secondary organic aerosol, Atmos. Environ., 28, 189-193, 1994.

Pankow, J. F. and Asher, W. E.: SIMPOL.1: a simple group contribution method for predicting vapor pressures and enthalpies of vaporization of multifunctional organic compounds, Atmos. Chem. Phys., 8, 2773-2796, doi:10.5194/acp-8-27732008, 2008.

Parshintsev, J., Nurmi, J., Kilpelainen, I., Hartonen, K., Kulmala, M., and Riekkola, M. L.: Preparation of beta-caryophyllene oxidation products and their determination in ambient aerosol samples, Anal. Bioanal. Chem., 390, 913-919, 2008.

Pathak, R. K., Yao, X. H., Lau, A. K. H., and Chan, C. K.: Acidity and concentrations of ionic species of PM2.5 in Hong Kong, 
Atmos. Environ., 37, 1113-1124, 2003.

Pathak, R. K., Louie, P. K. K., and Chan, C. K.: Characteristics of aerosol acidity in Hong Kong, Atmos. Environ., 38, 2965-2974, 2004.

Perri, M. J., Lim, Y. B., Seitzinger, S. P., and Turpin, B. J.: Organosulfates from glycolaldehyde in aqueous aerosols and clouds: laboratory studies, Atmos. Environ., 44, 2658-2664, 2010.

Pio, C., Alves, C., and Duarte, A.: Organic components of aerosols in a forested area of central Greece, Atmos. Environ., 35, 389401, 2001.

Rudzinski, K. J., Gmachowski, L., and Kuznietsova, I.: Reactions of isoprene and sulphoxy radical-anions - a possible source of atmospheric organosulphites and organosulphates, Atmos. Chem. Phys., 9, 2129-2140, doi:10.5194/acp-9-2129-2009, 2009.

Sakulyanontvittaya, T., Duhl, T., Wiedinmyer, C., Helmig, D., Matsunaga, S., Potosnak, M., Milford, J., and Guenther, A. Monoterpene and sesquiterpene emission estimates for the United States, Environ. Sci. Technol., 42, 1623-1629, 2008.

Shu Y. and Atkinson, R.: Rate constants for the gas phase reactions of $\mathrm{O}_{3}$ with a series of terpenes and $\mathrm{OH}$ radical formation from the $\mathrm{O}_{3}$ reactions with sesquiterpenes at $296 \pm 2 \mathrm{~K}$, Int. J. Chem. Kinet., 26, 1193-1205, 1994.

Shu, Y. and Atkinson, R.: Atmospheric lifetimes and fates of a series of sesquiterpenes, J. Geophys. Res.-Atmos., 100, 7275$7281,1995$.
Surratt, J. D., Kroll, J. H., Kleindienst, T. E., Edney, E. O., Claeys, M., Sorooshian, A., Ng, N. L., Offenberg, J. H., Lewandowski, M., Jaoui, M., Flagan, R. C., and Seinfeld, J. H.: Evidence for organosulfates in secondary organic aerosol, Environ. Sci. Technol., 41, 517-527, 2007a.

Surratt, J. D., Lewandowski, M., Offenberg, J. H., Jaoui, M., Kleindienst, T. E., Edney, E. O., and Seinfeld, J. H.: Effect of acidity on secondary organic aerosol formation from isoprene, Environ. Sci. Technol., 41, 5363-5369, 2007b.

Surratt, J. D., Gómez-González, Y., Chan, A. W. H., Vermeylen, R., Shahgholi, M., Kleindienst, T. E., Edney, E. O., Offenberg, J. H., Lewandowski, M., Jaoui, M., Maenhaut, W., Claeys, M., Flagan, R. C., and Seinfeld, J. H.: Organosulfate formation in biogenic secondary organic aerosol, J. Phys. Chem. A, 112, 8345-8378, 2008.

Surratt, J. D., Chan, A. W. H., Eddingsaas, N. C., Chan, M. N., Loza, C. L., Kwan, A. J., Hersey, S. P., Flagan, R. C., Wennberg, P. O., and Seinfeld, J. H.: Reactive intermediates revealed in secondary organic aerosol formation from isoprene, P. Natl. Acad. Sci. USA, 107, 6640-6645, 2010.

Winterhalter, R., Herrmann, F., Kanawati, B., Nguyen, T. L., Peeters, J., Vereecken, L., and Moortgat, G. K.: The gas-phase ozonolysis of beta-caryophyllene $\left(\mathrm{C}_{15} \mathrm{H}_{24}\right)$, Part 1: an experimental study, Phys. Chem. Chem. Phys., 11, 4152-4172, 2009. 